\title{
RÉQUIEM POR EL MANDATO REPRESENTATIVO
}

ANTONIO TORRES DEL MORAL 


\section{SUMARIO}

1. OBJETO DE ESTE ESTUDIO. 2. EL INSTITUTO DEL MANDATO REPRESENTATIVO EN EL ORDENAMIENTO CONSTITUCIONAL ESPAÑOL: 2.1. Sistema electoral y titularidad de los escaños. 2.2. Doctrina del Tribunal Constitucional. 3. REFORMA ELECTORAL Y TRANSFUGUISMO: 3.1. La reforma y su elemental concepto de transfuguismo. 3.2. De la estabilidad política municipal a la irresponsabilidad del equipo gobernante. 4. LA REFORMA ELECTORAL Y EL PROBLEMA DEL TERRORISMO: 4.1. Naturaleza jurídica del supuesto legal de pérdida del escaño: 4.1.1. Naturaleza parlamentaria, no electoral del supuesto. 4.1.2. Una supuesta condición resolutoria. 4.2. Ilegalización de un partido y autodisolución: el problema de los escaños. 4.3. Inicio y perfeccionamiento de la relación representativa. 4.4. Razón de Estado y razón jurídica: intransitividad de la ilegalidad. 4.5. Una cuestión de procedimiento. 4.6. Convicción moral versus principios jurídicos. 5. REPLANTEAMIENTO DEL PROBLEMA: ¿HUBO ALGUNA VEZ MANDATO REPRESENTATIVO?: 5.1. Origen y naturaleza del mandato representativo. 5.2. Separación de elección y representación: relación representativa y soberanía nacional. 5.3. El instituto de la revocación. 5.4. Un sistema de representación abocado a la parálisis y a su necesario falseamiento. 5.5. Los partidos políticos ocupan el vacío del sistema: hacia el mandato imperativo de partidos. 5.6. Representación e identidad. 6. DE NUEVO CON LA REFORMA ELECTORAL ESPAÑOLA: 6.1. El mandato de partidos, a la vista. 6.2. Consideraciones finales: el porvenir de la reforma. 


\title{
RÉQUIEM POR EL MANDATO REPRESENTATIVO
}

\author{
POR \\ ANTONIO TORRES DEL MORAL \\ Catedrático de Derecho Constitucional

\section{OBJETO DE ESTE ESTUDIO}

No es necesario que nos detengamos ni un instante en resaltar que el terrorismo ha sido uno de los problemas más acuciantes de la sociedad española en los últimos cuarenta años y que, instaurada la democracia, se convirtió seguramente en el más grave obstáculo para su consolidación. Tampoco necesita especial explicación que la democracia española, acaso para no merecer el reproche (!) de ser militante, no ha utilizado durante más de veinte años todas las armas compatibles con la juridicidad estatal para combatir dicha lacra en defensa de los valores superiores del Ordenamiento jurídico que, conforme al artículo primero de nuestra norma suprema, son propugnados por nuestro Estado de Derecho.

Sin embargo, hace ya casi una década el Estado español cambió su actitud respecto de los partidos que mantenían identidad o connivencia con el terrorismo, disponiendo, mediante la Ley Orgánica 6/2002, de 27 de junio, de Partidos Políticos, por una parte, un procedimiento de defensa y consolidación del régimen democrático, consistente en la posible ilegalización de partidos que justificaban la violencia como método o que estaban en connivencia o servían de instrumento a organizaciones terroristas; $y$, por otra, la prohibición de presentar candidaturas a las agrupaciones de electores que fueran continuación de partidos políticos ilegalizados y disueltos o suspendidos por estos mismos motivos. 
Las formaciones políticas más consistentes del sistema político español también se han preocupado durante mucho tiempo del fenómeno conocido como transfuguismo y han pactado actitudes comunes para ponerle freno, fórmula que, sin embargo, no ha dado el fruto apetecido.

Hace unos meses han sido aprobadas tres leyes orgánicas de reforma de la Ley Orgánica de Régimen Electoral General (en adelante, LOREG), de las que sólo dos se ocupan de los fenómenos aludidos (la restante ha modificado la papeleta electoral para el Senado).

La Ley Orgánica, la 2/2011, de 28 de enero, modifica diversos aspectos del régimen electoral, como son el censo, el voto de los inmigrantes en España, el voto de los españoles en el extranjero, la campaña electoral, la jornada de votación, etcétera, amén de encarar el problema del transfuguismo.

Por su parte, de las varias medidas que se adoptan en la Ley Orgánica 3/2011, de igual fecha, mencionamos las que tienen una relación más directa con el objeto de este estudio, que, sin embargo, solo versará sobre una de ellas. Son las siguientes:

1. Ha corregido adecuadamente una imprevisión de la Ley de Partidos y extendido la prohibición de presentar candidaturas a todas las demás formaciones políticas, sean partidos, coaliciones o federaciones de partidos, en los que pudieran concurrir las causas que dicha ley perseguía sólo en las agrupaciones de electores: su identidad o su carácter de prolongación o continuidad de otra formación ya ilegalizada.

2. Ha ampliado los plazos de impugnación de tales candidaturas y de resolución de los recursos correspondientes. Con esto sale al paso de una táctica empleada por las formaciones políticas afines al terrorismo de presentar sus candidaturas y sus recursos al última hora; dados los plazos perentorios y preclusivos de la legislación electoral, los Tribunales Supremo y Constitucional tenían que examinar en breves días cientos de candidaturas integradas por miles de candidatos, lo que provocaba errores, casi siempre a favor del derecho fundamental de participación política, o, lo que es igual, en beneficio de la formación política sometida a examen.

3. Las dos siguientes medidas pisan ya un terreno más delicado. En una de ellas el Estado de Derecho se cubre frente a eventualidades que pudieran sorprenderlo, como es la de que, pese a las previsiones anteriores, después de celebrada la votación se presenten dudas o evidencias de connivencia con el terrorismo de una de las formaciones políticas que presentaron candidaturas y obtenido escaños. Llegado el caso, la ley habilita una solicitud de suspensión cautelar de la proclamación de candidatos electos pertenecientes a la o las formaciones políticas contra las que se vaya a promover, en los quince días siguientes, un 
procedimiento de ilegalización o un incidente de ejecución de una sentencia ya habida de ilegalización; la suspensión cautelar durará hasta que se resuelva la demanda.

Hay en esta previsión ciertas imprecisiones que se compadecen mal con la primacía de los derechos: si la causa de ilegalización no prospera, se ha hecho perder durante un cierto tiempo a algunos ciudadanos su derecho de participación política a través de sus representantes, y a los electos no proclamados su derecho al cargo, ambos reconocidos por el artículo 23 de la Constitución.

4. La otra medida consiste en incluir como causa de inelegibilidad de una persona su condena, aunque no sea firme, por algunos delitos, como los de rebelión, terrorismo, etcétera, cuando en ella se establezca la pérdida de los derechos políticos del condenado. Cierto que hay condena, y eso ya tiene un valor cierto en un Estado de Derecho con un Poder Judicial independiente. Pero de nuevo debe primar la interpretación favorable al derecho, concretamente el derecho a la presunción de inocencia ante la eventualidad de que dicha condena sea anulada por instancia superior o por el Tribunal Constitucional.

Pero son otros los aspectos de una y otra ley que más interesan al presente estudio. De la ley orgánica 2/2011, vamos a centrarnos en el intento de embridar, ahora normativamente, esa importante anomalía de nuestro sistema democrático representativo en el ámbito municipal, cual es el transfuguismo. A tal fin, modifica la redacción del artículo 197.1 de la LOREG, que regula la moción de censura al Alcalde.

$\mathrm{Y}$, por lo que concierne a la ley orgánica 3/2011, nos ocuparemos del nuevo apartado $4^{\circ}$ que añade al artículo $6^{\circ}$ de la LOREG para introducir una nueva causa de incompatibilidad (así la denomina la ley) en la que incurren los representantes electos de candidaturas presentadas por formaciones políticas posteriormente declaradas ilegales por sentencia judicial firme.

Ambos extremos, tan diferentes entre sí, convergen en su posible contradicción con el instituto del mandato representativo, y a dilucidarlo están dedicadas las siguientes páginas haciendo abstracción de otras facetas, acaso igualmente interesantes, que uno y otro presentan.

Una nota adicional parece todavía pertinente: aunque el análisis de la relación representativa puede llevarse a los distintos ámbitos territoriales en los que ésta tiene lugar (nacional, regional y local) y así lo hacemos respecto de los problemas que plantea el terrorismo, el legislador ha circunscrito al ámbito local la reforma relativa al transfuguismo. Por eso, cuando nos referimos al texto legal expreso, hablamos sólo de concejales, y los demás casos a todos ellos, aunque, por economía hayamos preferido a veces nombrar solamente a los diputados. 


\section{EL INSTITUTO DEL MANDATO REPRESENTATIVO EN EL ORDENAMIENTO CONSTITIUCIONAL ESPAÑOL}

\subsection{Sistema electoral y titularidad de los escaños}

Cuando, al principio del actual régimen constitucional español, algunos diputados y senadores abandonaron su grupo parlamentario para pasar a otro o al Grupo Mixto, se oyeron opiniones críticas, sobre todo en el seno de los partidos afectados, defendiendo que los escaños les pertenecían porque los diputados habían sido elegidos en una candidatura cerrada y bloqueada, encabezada por las siglas de un partido, motivo por el que no tenían derecho, si lo abandonaban, a retener un escaño que no ganaron por sus virtudes personales, sino por su encuadramiento partidario; máxime cuando, al menos por lo que se refiere al Congreso de los Diputados, las normas electorales prevén la eventual sustitución del diputado dimitido por el primer candidato que quedó sin escaño.

No creemos que esta opinión (la titularidad de los escaños por parte de las formaciones políticas en cuyas candidaturas han sido elegidos los representantes políticos) allane las dificultades; antes bien, crea otras, como, según veremos en el presente estudio, la de cuestionar los sujetos y naturaleza de la relación representativa y, por tanto, la vigencia del mandato representativo en nuestro Ordenamiento.

Ordenamiento que responde a otros criterios. En él los partidos políticos no son órganos del Estado, sino instrumentos de participación ciudadana y de funcionamiento de los órganos estatales, mientras que los diputados son miembros de un órgano estatal, el Parlamento, y las actas o credenciales de la elección se extienden nominalmente a los diputados electos, no al partido político de referencia. Todo lo cual puede decirse igualmente de los concejales.

La conclusión es sencilla: los miembros de un órgano del Estado no pueden ser formalmente nombrados ni cesados por una organización política extraestatal.

En términos jurídicos, el pueblo vota candidatos, no partidos (en el Senado es mucho más claro todavía, puesto que el voto es nominal). El partido interviene en el proceso activándolo, animándolo, facilitándolo al proporcionar candidatos con clara identificación política y — se supone- preparados por el propio partido. Pero el Parlamento está integrado por diputados y senadores, no por partidos políticos, que son formaciones privadas extraparlamentarias, ni por grupos parlamentarios, que tampoco son miembros de la Cámara, sino asociaciones políticas investidas de funciones parlamentarias dirigidas a la activación y agilización de su funcionamiento. 
No obstante, este dictamen jurídico no resuelve satisfactoriamente todos los flecos del problema y ha suscitado la discrepancia de parte de la doctrina. F. J. BASTIDA se pronuncia en favor de la pérdida del escaño por parte del representante local en caso de abandono voluntario del partido o del grupo político de la Corporación Local, y también en el supuesto de expulsión, siempre que ésta se haya decidido con las garantías legalmente establecidas ${ }^{1}$. El argumento principal es el de la relevancia — no sólo política, sino también jurídica- de la intervención electoral del partido mediante la confección de la candidatura y del programa; por eso, al quebrar la vinculación del representante individual con el partido, quiebra su vinculación con el electorado y quiebra también la lealtad que el representante debe al electorado a través del programa al que ligó su inclusión en la candidatura. R. L. BLANCO VALDÉS también se inclina a esta posición ${ }^{2}$. Y F. CAAMAÑO ha defendido igualmente que el mandato parlamentario está informado y determinado por la relación diputado-partido 3 .

En este último sentido se pronuncia la Constitución portuguesa, como excepción, por ahora, entre las democracias representativas actuales.

Una de las ideas que se contemplan y que incluso se han puesto en práctica como disuasorias de la independencia de los parlamentarios y de eventuales indisciplinas es la de desposeer al diputado rebelde de todos sus cargos parlamentarios representativos del grupo que se siente traicionado por él, salvo los mínimos que exige el Reglamento de la Cámara (por ejemplo, que pertenezca, al menos a una Comisión). Es una forma de declarar una casi «muerte parlamentaria» del diputado o senador en cuestión. Otra de las medidas en estudio es la de introducir en nuestro Ordenamiento la figura del diputado (o senador) no inscrito, con efectos semejantes porque reduce considerablemente la actividad de tal parlamentario.

\subsection{Doctrina del Tribunal Constitucional}

En términos generales, el Tribunal Constitucional se ha hecho eco del planteamiento que aquí sostenemos y lo ha extendido a todo tipo de vínculo repre-

1 BASTIDA, F. J.: «Derecho de participación a través de representantes y función constitucional de los partidos políticos», Revista Española de Derecho Constitucional, n 21, Madrid, 1987, págs. 209 ss.

2 BLANCO VALDÉS, R. L.: Los partidos políticos, Tecnos, Madrid, 1990, págs. 154-157.

3 CAAMAÑO, F.: El mandato parlamentario, Centro de Estudios Constitucionales, Madrid, 1993.

(C) UNED. Revista de Derecho Político 
sentativo establecido electoralmente en nuestro sistema político, tanto a nivel nacional como autonómico y municipal. Esto último lo llevó a declarar inconstitucional el artículo 11.7 de la entonces vigente Ley de Elecciones Locales, que ligaba la conservación del cargo de concejal o de diputado provincial de una persona al mantenimiento de su relación con el partido político en cuya candidatura fue elegida.

En contra del criterio del Tribunal Supremo, que había resuelto ya varios casos aplicando dicho precepto y privando al representante local de su escaño, el Tribunal Constitucional ${ }^{4}$ apreció la existencia de un mandato representativo en toda relación entre los ciudadanos y sus representantes. Sinteticemos dicha doctrina:

a) Ante todo, el derecho de acceso a los cargos públicos (art. 23.2) comprende el de permanecer en ellos durante el tiempo de mandato, con lo cual se trata de dar efectividad al derecho de participación de los ciudadanos a través de sus representantes (art. 23.1).

b) No es inimaginable, ciertamente, un sistema democrático en el que los representantes estén vinculados, directa o indirectamente, al mandato imperativo de los representados. Pero no es así en nuestro sistema y aún lo es menos que dependan del mandato imperativo de los partidos. Es discutible la revocación por parte de los electores, pero no cabe la revocación por los partidos.

c) Como los sujetos del derecho de participación son los ciudadanos, no los partidos políticos, los representantes elegidos lo son de aquéllos, no de éstos. Mirando la cuestión a través del prisma de los hechos, la elección es resultado de una motivación compleja en la que sobre el elector pesa la personalidad del candidato y también su presentación por un partido. Pero, en términos jurídicos, los artículos 6 23, 68, 69, 70 y 140 de la Constitución son inequívocos: los ciudadanos eligen personas, no partidos políticos ni asociaciones.

d) Por último, advirtió que había dictaminado únicamente supuestos de expulsión del partido político, no casos de baja voluntaria en el mismo5 Sin embargo, en posteriores sentencias asimiló a estos efectos ambos supuestos ${ }^{6}$.

4 Así lo hace en STC 5/1983, de 4 de febrero; más cuidadamente en la 10/1983, de 21 de febrero y reiterativamente en las 16/1983, de 10 de marzo; 20/1983, de 15 de marzo, 28/1983 de 21 de abril; 29 y 30/1983, de 26 de abril, y 28/1984, de 28 de febrero.

5 ATC 11-I-1984.

${ }^{6}$ Cfr., por todas, STC 185/1993, de 31 de mayo. 
Empero, son atendibles igualmente algunos argumentos del voto particular emitido por varios magistrados en la primera de las sentencias mencionadas. Y, de otra parte, de la doctrina expuesta se extraen algunas consecuencias que no debemos dejar de anotar porque evidencian ciertos saltos lógicos en la extensión del mandato representativo al ámbito político local. Como dice R. Chueca, el Tribunal no consiguió, pese al notorio esfuerzo realizado, solventar todos los problemas ${ }^{7}$.

Y así observamos que, cuando la Constitución habla de la representación de todo el pueblo español, la refiere a las Cortes, no a cada una de sus Cámaras, ni a cada parlamentario, y cuando dice que las reuniones de parlamentarios no convocadas reglamentariamente no vinculan a la Cámara, ni ejercen sus funciones, ni ostentan sus privilegios (art. 67.3), parece confirmar la misma idea. Bien es verdad que el Congreso y el Senado, en cuanto órganos integrantes de las mismas, se considera que ostentan igual representación, como también —aunque en un principio el Tribunal Constitucional titubeó al respecto- los diputados y senadores en tanto que son miembros individuales igualmente integrantes de las Cortes.

Si trasladamos este planteamiento a otros ámbitos políticos distintos de las Cortes Generales, y concretamente a los Ayuntamientos, tendríamos igual resultado: no es que todos y cada uno de los concejales representen a todos y cada uno de los vecinos, sino el conjunto de aquéllos, reunidos reglamentariamente, al conjunto de éstos; pero también se estima que los concejales, como miembros del Ayuntamiento, ostentan igual representación.

En posteriores sentencias el Tribunal Constitucional se muestra menos seguro. Así, en cuanto al sujeto o ente receptor del voto, asegura ${ }^{8}$ que los electores no votan a personas, a candidatos individuales, sino a listas (sic) de candidatos, opinión jurídicamente errónea, porque se vota a los candidatos que figuran en las candidaturas colegiadas ${ }^{9}$, lo que es manifiestamente distinto. No podemos hacer a éstas, que no pasan de ser una cosa, un instrumento técnico-electoral de presentación de personas individuales como candidatos, los titulares del derecho de sufragio pasivo ${ }^{10}$.

7 CHUECA, R. «Sobre la irreductible dificultad de la representación política», Revista Española de Derecho Constitucional, n 21, Madrid, 1987, pág. 188.

8 SSTC 75/1985, de 21 de junio, y 31/1993, de 26 de enero.

9 STC 101/1983, de 18 de noviembre.

10 El término «listas», muy extendido y que el Tribunal emplea a veces es vulgar e impreciso, siendo preferible la expresión candidatura colegiada o plurinominal. 
En fin, en otra ocasión ${ }^{11}$ da por buena la regulación que hace la Ley Orgánica del Referendo del acceso gratuito de los grupos políticos a los medios de difusión de titularidad pública en las campañas referendales; esta Ley concede tal derecho a los grupos políticos con representación en las Cortes y dicha representación es medida por «el número de diputados obtenido en las últimas elecciones generales»; el Tribunal Constitucional acepta el criterio y, yendo más allá, niega toda trascendencia para el caso a los cambios de grupo parlamentario por parte de los diputados, con lo cual, parece que fija la representación en el momento electoral y niega efecto alguno, en cuanto al problema que comentamos, a los movimientos habidos en el seno de los grupos parlamentarios. No hace falta advertir que, conforme a las coordenadas teóricas que iremos trazando en este estudio, tal posición del alto Tribunal muestra una textura muy poco sólida.

\section{REFORMA ELECTORAL Y TRANSFUGUISMO}

\subsection{La reforma y su elemental concepto de transfuguismo}

Como hemos adelantado, la ley orgánica 2/2011 modifica la redacción del artículo 197.1 de la LOREG, que regula la moción de censura al Alcalde, cuyo párrafo a) dice ahora así:

«a) La moción de censura deberá ser propuesta, al menos, por la mayoría absoluta del número legal de miembros de la Corporación y habrá de incluir un candidato a la Alcaldía, pudiendo serlo cualquier Concejal cuya aceptación expresa conste en el escrito de proposición de la moción.

En caso de que alguno de los proponentes de la moción de censura formara o haya formado parte del grupo político municipal al que pertenece el Alcalde cuya censura se propone, la mayoría exigida en el párrafo anterior se verá incrementada en el mismo número de concejales que se encuentren en tales circunstancias.

Este mismo supuesto será de aplicación cuando alguno de los concejales proponentes de la moción haya dejado de pertenecer, por cualquier causa, al grupo político municipal al que se adscribió al inicio del mandato»

Episodios de transfuguismo ha habido siempre en el parlamentarismo y el tránsfuga, en ocasiones, ha pasado a ser un hombre venerado como un gran benefactor de la Humanidad. Churchill cambió de partido, bien es cierto que no durante una legislatura, pero sirva como ejemplo de que en este terreno hay que manifestarse con prudencia.

${ }^{11}$ STC 63/1987, de 20 de mayo. 
Porque no siempre el tránsfuga es «el malo». A este respecto es de recordar un artículo de prensa publicado por F. RUBIO LLORENTE hace años llamando la atención sobre casos en los que la valoración ética se invierte en contra del partido político en el que el supuesto tránsfuga milita o militaba. En ocasiones, a mi juicio, es el partido el que se separa de su programa en tanto algunos diputados individuales se mantienen fieles al mismo.

El ejemplo más evidente fue el del Partido Socialista Obrero Español (en adelante, PSOE) en la II Legislatura, cuando, tras haberse opuesto en las Cortes anteriores al ingreso de España en la OTAN y haber prometido la salida de ella ( «si se entra por una votación parlamentaria, se saldrá por otra votación parlamentaria») e insistir en ello durante la campaña electoral, ya de modo más ambiguo ( $O T$ TAN: de entrada no»), pasó, una vez alcanzado el Gobierno, a defender la permanencia. Sólo unos pocos diputados se opusieron a ello y votaron en contra. Sin duda, fueron éstos los que se mantuvieron fieles al programa del partido en tanto que los casi doscientos diputados restantes, con el Secretario General y el Vicesecretario General del Partido a la cabeza, se separaron de él. El hecho de que, desde el punto de vista político y atendiendo los intereses de la nación, la opinión pública haya acabado por reconocer el pleno acierto de aquel cambio de postura en nada empalidece lo que decimos. Realmente, en este episodio no hubo transfuguismo, pero pudo haberlo si, en señal de protesta, los diputados fieles al programa, hubieran abandonado el Grupo Parlamentario Socialista e ingresado en el Grupo Mixto. ¿Quiénes habrían sido los tránsfugas entonces? Jurídicamente, éstos; políticamente, los que votaron contra su propio programa. Pero el Derecho no puede entrar a dirimir desavenencias políticas internas de este carácter.

Pongamos otro ejemplo, verdaderamente ilustrativo del comportamiento torticero no del diputado o senador, sino del partido y del grupo parlamentario. Acaeció en el Senado constituyente. El senador por designación regia Torcuato Fernández Miranda se inscribió en el Grupo Parlamentario de Unión de Centro Democrático (en adelante, UCD), pero a los pocos meses, por su disidencia respecto del diseño que se hacía de la organización territorial del Estado, se pasó al Grupo Mixto. Entonces UCD, temiendo que, por su personalidad y experiencia, participara en los debates mucho más de lo que había podido hacer hasta entonces, «trasladó» a varios senadores propios al Grupo Mixto (digámoslo con corrección jurídica: ordenó a varios parlamentarios propios que abandonaran su grupo parlamentario y se inscribieran en el Mixto) para así restar a Fernández Miranda protagonismo político. Fue un fraude evidente al reglamento parlamentario, pero no del senador de referencia, sino de UCD (partido y grupo parlamentario). En cuanto a los senadores «emigrantes», no fueron ni siquiera tránsfugas, sino senadores heteroproyectados por su 
partido hacia el fraude; con todas las bendiciones jurídico-formales, eso sí, pero con un estilo político deplorable.

Por eso, en el fenómeno del transfuguismo hay que mirar caso por caso, porque muchos supuestos de cambio de voto o de grupo parlamentario no lo son propiamente. Es lo que sucede, a nuestro entender:

1) Cuando un concejal independiente o de un tercer partido que deshace el empate entre los dos partidos más importantes en la investidura de Alcalde (y correspondiente formación del Gobierno municipal), pero cambia de posición durante la legislatura y apoya una moción de censura con candidato alternativo de la Oposición. Dicho concejal no es tránsfuga de nada ni de nadie porque no se cambia de grupo político municipal, sino de opción política, lo cual es perfectamente legítimo ${ }^{12}$.

2) Cuando esos mismos actos son protagonizados por un grupo municipal o parlamentario (A) para sellar un pacto de legislatura a fin de apoyar un Gobierno de otro partido (B), o para gobernar con él en coalición, pero después apoyan a otro grupo $(\mathrm{C})$ para una moción de censura, o bien denuncian el pacto y pasan a la Oposición forzando al grupo del Gobierno a pactar otras medidas.

3) Cuando un partido incorpora personas independientes a sus candidaturas, buscando obtener con ello réditos electorales por su gesto de aperturismo, de ausencia de dogmatismo y de reconocimiento de la valía personal por encima de las militancias, y luego estas personas se comportan de forma efectivamente independiente, votando en contra de algunas propuestas de su grupo municipal o parlamentario e incluso abandonándolo. Un independiente que se comporta de modo independiente no es, en modo alguno, un tránsfuga, pero así es considerado no sólo de modo sorprendente, sino manifiestamente inconstitucional por la reforma electoral que estudiamos.

Como también es considerado tal, y de nuevo incorrectamente a mi juicio, el concejal que, por motivos de corrupción generalizada de su grupo municipal, o, llevando el argumento al límite, de todo su partido en la localidad, se separa de ambos.

\subsection{De la estabilidad política municipal a la irresponsabilidad del equipo gobernante}

La reforma ha pretendido disuadir todo tipo de transfuguismo municipal al privar al «tránsfuga» de su facultad de censura, que es el arma mayor de control

12 Hacemos abstracción de motivaciones espurias, siempre posibles, e incluso probables, pero que habría que demostrar. 
frente al equipo de gobierno o, en su caso, frente el Alcalde, con la agravante de que considera fenómenos de transfuguismo episodios que no lo son.

Con todo, no satisfecho el legislador orgánico con tamaños disparates, veremos a continuación cómo la reforma analizada nos depara sorpresas mucho más llamativas y no menos inconstitucionales. Veamos para ello las consecuencias políticas que extrae el legislador de su tan novedoso como torpe concepto de transfuguismo.

1) Sea un Ayuntamiento con dos grupos políticos municipales. El Grupo A tiene 8 concejales y el B 7. El Grupo B no tiene efectivos suficientes para presentar la moción de censura porque, como hemos podido leer en el texto legal transcrito, se precisa la mayoría absoluta de concejales para ello.

He aquí un primer disparate: la presentación de una moción de censura requiere tanto apoyo como su aprobación, lo que contradice la lógica y la tradición parlamentaria liberal, menos exigente siempre con el trámite de presentación para así dar opción al debate y, como resultado del mismo, a una eventual realineación de los miembros de la Cámara. Además, ¿para qué votar una moción que de antemano tiene en su favor, de modo fehaciente y firmado, la mayoría absoluta? Únicamente se explicaría por la necesidad formal de levantar acta de la sesión y del resultado.

2) Con los mismos datos numéricos anteriores, si surgen discrepancias en el grupo gobernante y uno o varios de sus miembros firmaran junto al grupo opositor una moción de censura, seguirían sin cumplirse los nuevos requisitos legales, puesto que, en tal caso, la mayoría exigida para la propuesta se incrementaría en tantas unidades como concejales disidentes del grupo de gobierno, por lo que a la propuesta siempre le faltaría una firma.

Desatino segundo: en este supuesto se está exigiendo para la presentación de la moción más apoyos que para su aprobación, con lo que el reproche que hemos hecho en el supuesto primero, hemos de incrementarlo ahora. Como hemos de incrementar igualmente el comentario acerca de la futilidad de la votación y de su única justificación formal.

3) Sigamos operando con los mismos datos anteriores, pero extremando el supuesto: el Grupo A, gobernante, se divide en dos: tres concejales más el Alcalde, de un lado, y cuatro de otro. Esto puede deberse a motivaciones muy diversas, no todas confesables, pero tampoco todas merecedoras del nombre de transfuguismo, puesto que puede obedecer a una verdadera disidencia interna del grupo municipal e incluso responder a grietas surgidas entre distintas corrientes internas del partido político, o incluso a la ruptura de la coalición electoral que ganó las elecciones y la ulterior investidura. Pues bien, tanto si los seis disidentes forman otro Grupo como si intentan actuar con el Grupo de la Oposición permaneciendo en el suyo de origen, siguen sin cumplir las

(C) UNED. Revista de Derecho Político 
nuevas exigencias para censurar al Alcalde. Dígase lo mismo si, por llevar el argumento al límite, son todos los concejales del grupo gobernante e incluso su propio partido los que discrepan del Alcalde, lo que vale tanto como decir que

Tercer despropósito: en supuestos como éste, el Alcalde queda inmunizado respecto de cualquier descontento de los propios concejales e incluso de su partido.

4) Un concejal abandona el grupo opositor en el que figuraba y pasa al Mixto, pero sigue coincidiendo con aquél en la opinión política desfavorable que le merece el Alcalde y su grupo gobernante. Pues bien, tal concejal deja de contar para una moción de censura porque su firma se traduce en el incremento de una unidad en la mayoría exigida para la presentación de la moción.

Cuarto dislate: los concejales de un grupo opositor, si quieren seguir contando para un posible relevo del equipo gobernante, deben permanecer en su grupo municipal a todo evento y no cambiar a otro, sea cual fuere, por muchas y graves que sean las desavenencias surgidas con su grupo inicial.

Si del casuismo pasamos a la formulación de un enunciado general sobre este aspecto de la reforma, podemos hacerlo en los términos siguientes:

1. Todo Ayuntamiento cuyo Alcalde fue en el inicio de la legislatura elegido por la mayoría absoluta de su grupo político municipal, no puede ser censurado y ni siquiera corre el riesgo de que se pueda presentar una moción en tal sentido por cuanto debe ser suscrita por la mayoría absoluta de los concejales integrantes del Ayuntamiento, suma inaccesible al resto de los concejales de los demás grupos.

2. Ni siquiera se le puede presentar la moción de censura en la hipótesis de que en su grupo surjan desavenencias, rupturas y abandonos porque el requisito de la mayoría absoluta para su presentación experimenta un incremento de tantas unidades como supuestos «tránsfugas» la firmen. De manera que si no firman la moción, no puede presentarse por no reunir la Oposición la mayoría absoluta; y si la firman, tampoco, porque en tal caso la exigencia de mayoría absoluta se incrementa en igual medida.

Son muchos cientos, acaso miles, los pequeños municipios españoles en los que se dan las condiciones relatadas ${ }^{13}$, en los cuales no es que las mociones de censura no puedan prosperar, lo que sería grave desde una óptica sanamente de-

13 Aunque a las elecciones municipales suelen presentarse candidaturas espontáneas de independientes y de líderes locales, lo estadísticamente normal es la presentación de candidaturas de los partidos consolidados, y es conocido el bipartidismo de muchas Comunidades Autónomas: Murcia, Castilla La Mancha, Castilla y León, La Rioja. 
mocrática, sino que ni siquiera pueden ser presentadas, lo que es abiertamente antidemocrático y, por supuesto, inconstitucional.

La razonable preocupación de los partidos y de los poderes públicos españoles por la estabilidad política municipal debería haber llevado al legislador orgánico, en su caso, a disponer la presidencialización de su sistema de gobierno, con la elección directa de los alcaldes y otras medidas pertinentes. Pero el camino elegido es una mezcla de parlamentarismo y presidencialismo difícilmente inteligible y que a buen seguro suscitará más problemas de los que se han querido resolver.

Las conclusiones que se extraen de esta poco meditada reforma pueden ser formuladas del modo que sigue:

1. Con los datos numéricos arriba manejados, los Alcaldes y sus equipos de gobierno son políticamente irresponsables, contra lo preceptuado en el artículo 9.3 de la Constitución, que consagra como uno de los principios fundamentales del Estado democrático de Derecho el de responsabilidad de los poderes públicos.

2. El absurdo llega al límite si se lo formula absurdamente, a saber: con tales datos, es imposible la presentación de una moción de censura incluso si la respalda el 100 por 100 de los concejales, es decir, incluso si la firma jel propio Alcalde! Es lo que pasa cuando improvisan en matemáticas quienes las ignoran por completo y tampoco andan muy dotados de sentido común.

3. Los concejales disidentes de sus grupos que tengan la debilidad de ser congruentes y pasar a otro distinto, sea éste cual fuere, se verán privados de una facultad tan esencial e inherente a la democracia representativa como la del gobierno de la mayoría, cual es el control de la minoría y la exigencia de responsabilidad al equipo gobernante, con la posibilidad de llegar a ser mayoría y gobernar.

4. Siempre con los datos que hemos utilizado en los supuestos anteriores, la reforma se vuelve contra sí misma, puesto que, siendo su finalidad la de reforzar a los partidos políticos frente a los disidentes que surjan en sus filas, si el disidente interno es el Alcalde, ni su propio partido puede nada contra él durante el tiempo de su mandato.

5. Cierto es que en tales casos el Alcalde no podrá gobernar porque el Pleno rechazará su proyecto de Presupuestos y demás iniciativas, pero tampoco se le podrá remover de su cargo: el Ayuntamiento se paraliza, pero el Alcalde sigue. No hace falta añadir que este remedio es políticamente mucho más pernicioso que la enfermedad que quiere combatir y es además jurídicamente contradictorio con el principio constitucional de responsabilidad de los poderes públicos.

6. En consecuencia, fijar la relación representativa en el momento electoral sin posible alteración ulterior no equivale automáticamente a estabilidad políti-

(C) UNED. Revista de Derecho Político 
ca municipal, sino que puede conducir a la parálisis del Ayuntamiento y a la irresponsabilidad.

\section{LA REFORMA ELECTORAL Y EL PROBLEMA DEL TERRORISMO:}

\subsection{Naturaleza jurídica del supuesto legal de pérdida del escaño}

El texto que nos interesa de la reforma referente al terrorismo reza del siguiente tenor:

«4. En todo caso serán incompatibles las personas electas en candidaturas presentadas por partidos o por federaciones o coaliciones de partidos declarados ilegales con posterioridad por sentencia judicial firme, así como los electos en candidaturas presentadas por agrupaciones de lectores declaradas vinculadas a un partido ilegalizado por resolución judicial firme. La incompatibilidad surtirá efecto..., salvo que éste [el interesado] formule, voluntariamente... una declaración expresa e indubitada de separación y rechazo respecto de las causas determinantes de la declaración de ilegalidad del partido... en cuya candidatura hubiese resultado electo; o, en su caso, del partido al que se hubiese declarado vinculada la agrupación de electores en cuya candidatura hubiere resultado electo».

El precepto continúa declarando definitiva la causa de incompatibilidad si posteriormente a la declaración referida, el electo se retracta de ella o la contradice mediante hechos, omisiones o manifestaciones, y aplicando el mismo régimen a los integrantes de tales candidaturas que sean llamados a cubrir los escaños vacantes, incluidos los suplentes.

\subsubsection{Naturaleza parlamentaria, no electoral, del supuesto}

Esta reforma significa un último intento, hasta ahora, de erradicar la presencia de elementos terroristas en las instituciones representativas españolas. Pero el asunto es delicado y debe ser abordado con el tino debido ${ }^{14}$.

${ }^{14}$ Cuando esta ley era un simple borrador, ya me pronuncié sobre él en algunos foros y brevemente en una nota de mi trabajo «Terrorismo y principio democrático», Revista de Derecho Político (en adelante $R D P$ ), $\mathrm{n}^{\circ} 78$, UNED, Madrid, 2010, nota 81, pág. 151, llamando la atención, con el resultado negativo previsible, acerca del cuidado que había que poner en su redacción para no errar el envite. 
El primer comentario que merece este desgraciado precepto es que declara incompatibles a personas, cuando en una democracia, por definición, todas las personas son igualmente dignas y compatibles con sus valores. Ya se entiende que es un lapsus del legislador, pero en un Estado democrático de Derecho el legislador no puede incurrir en él descalificando personas en vez de conductas.

Observemos que el texto que nos ocupa habla de la incompatibilidad en que se encuentra para el desempeño de su cargo la persona elegida en la candidatura de un partido o formación política que haya sido ilegalizada por motivos de terrorismo. En algún debate académico se ha esgrimido también el concepto de inelegibilidad, adjetivándola de sobrevenida (igual adjetivo se suele predicar de esta supuesta incompatibilidad, incluso así se la llama en el preámbulo de la ley). A mi juicio, no estamos en presencia de ninguno de estos dos institutos.

Fue un claro error del constituyente que, tras incorporar un principio de regulación de la incompatibilidad y de la inelegibilidad en un mismo precepto (art. 70), ordenara su desarrollo normativo a una ley electoral, siendo así que la incompatibilidad no es materia propiamente electoral, sino parlamentaria, por lo que la fuente apropiada para regularla debería haber sido el reglamento de cada Cámara ${ }^{15}$. El hecho de la coincidencia material de algunas causas de inelegibilidad y de incompatibilidad no desdice su diferente naturaleza jurídica ni, por ende, el mayor acierto que habría significado ordenar sus desarrollos normativos, uno a la legislación electoral y otro a los reglamentos de las Cámaras. Pero el error está en la norma suprema y no cabe reprochárselo ahora al legislador orgánico.

En lo que éste yerra al regular el supuesto que analizamos es en pretender subsanar una incompatibilidad sobrevenida, dado que este instituto no es predicable de las personas, sino de los cargos, habiéndose de optar por uno de ellos, y en este caso no los hay.

Tampoco se trata, como se ha dicho en ciertos ámbitos jurídicos, de una causa de inelegibilidad sobrevenida, concepto harto extravagante por cierto. La inelegibilidad es siempre previa a la elección, aunque se descubra después, que es quizá lo que se quiere decir. Pero aquí no se descubre nada nuevo: el representante político pretendidamente afectado ha sido presentado a unas elecciones en una candidatura nada clandestina. De manera que hemos de acudir a otra categoría jurídica.

15 Llevando el problema al ámbito municipal, la fuente idónea es seguramente la Ley de Régimen Local. 


\subsubsection{Una supuesta condición resolutoria}

Lo que realmente se quiere hacer y no se acierta con el nombre ni con su naturaleza jurídica, es incorporar a la relación representativa una implícita condición resolutoria que, de cumplirse, exige su enervación o, de lo contrario, determina la extinción de dicha relación jurídica. Por eso sus efectos serían ex nunc (la no continuidad del mandato de diputado o concejal), y no ex tunc (la anulación de la elección), como habría de ser en el supuesto de esa llamada inelegibilidad sobrevenida.

Conforme a la reforma legal comentada, esta duda puede ser disipada con una simple declaración de separación o rechazo del acto o actos terroristas acaecidos. Pero resulta obvio que, en el caso de que esta regulación logre mantenerse en el Ordenamiento por ser considerada constitucionalmente correcta, tal declaración tampoco tendría naturaleza jurídica electoral, sino parlamentaria. Pues, en efecto, no revalidaría la elección habida meses o años antes, sino que perfeccionaría, en un momento determinado de la legislatura o de la duración del mandato, la situación jurídica del representante afectado, así como, forzosa y simultáneamente, perfeccionaría también la composición de la Cámara correspondiente.

$\mathrm{Y}$, como corresponde a la naturaleza del problema, no es de utilización apropiada a su resolución ningún criterio de Derecho electoral, sino de Derecho parlamentario (o asimilado en el ámbito municipal) en conexión necesaria con el tipo de representación habido en nuestro Ordenamiento, esto es, el mandato representativo.

\subsection{Ilegalización de un partido y autodisolución: el problema de los escaños.}

La cuestión central que se plantea reside en saber si la disolución de un partido que sea declarado ilegal comporta la decadencia del mandato de los diputados que fueron elegidos en sus candidaturas. Quienes responden afirmativamente se apoyan en la constitucionalización de la democracia de partidos. Quienes lo hacen negativamente, en el principio del mandato representativo ${ }^{16}$.

${ }^{16}$ Desde la ilegalización de Batasuna y de otras formaciones políticas (en realidad, el mismo partido con otros nombres) en 2003, incluso desde la aprobación de la Ley Orgánica de Partidos Políticos en el año anterior, la doctrina se ha ocupado insistentemente de este problema. Cfr., por todos, VÍRGALA FORURIA, E.: «El cerco judicial a los partidos políticos con vínculos terroristas»: de la STC 48/2003 al ATS de 18 de junio de 2003», en Jueces y Democracia, Madrid, 2004; del mismo autor: «Los partidos políticos ilícitos tras la LO 6/2002», Teoría y Realidad Constitucional (en 
Se suele citar como precedente, aunque no igual del todo, la ilegalización, en Alemania en 1952, del Partido Socialista del Reich, de ideología neonazi, y la subsiguiente decisión del Tribunal Constitucional Federal de la pérdida de sus escaños por considerar que quedaba rota la relación representativa entre el elector y los diputados, relación que el Tribunal estimó indirecta, esto es, que pasaba por la intermediación del partido que los incluía en sus candidaturas ${ }^{17}$. No había en el Ordenamiento alemán disposición normativa alguna que diera cobertura a la decisión del Tribunal, sino que éste hizo una sentencia creativa y normativa, innovando el Ordenamiento y haciendo un uso dudosamente constitucional (en realidad, fue inconstitucional sin duda alguna) de su potestad de control de la constitucionalidad de los partidos políticos. De ahí la polémica levantada con tal ocasión en Alemania y en el resto de Europa, en la que las opiniones estaban muy divididas.

Posteriormente, en 1956, se pronunció de igual modo sobre el Partido Comunista. La diferencia jurídica entre ambos casos estriba en que, en el segundo, la cuestión estaba ya regulada por la ley electoral aprobada unos meses antes, si bien cabe cuestionar su ortodoxia constitucional lo mismo que en el supuesto anterior. La doctrina dividió de nuevo su juicio sobre esta postura. A mi me parece jurídicamente deficiente y a explicarlo dedico las líneas siguientes.

El principio general consiste en el reconocimiento de que la calidad de diputado se funda en la elección popular y proviene del cuerpo electoral. Frente a ello, la pertenencia del candidato a un partido político comporta sólo un vínculo asociativo (o acaso menos, cuando no hay tal pertenencia, sino simple adhesión a su programa, como ocurre con los candidatos independientes), pero no incide sobre el título jurídico de la elección. Por consiguiente, la disolución del partido no debe tener más efecto que la disolución de ese vínculo asociativo interno, no el término de la relación del diputado con el Parlamento, como miembro suyo que es, y con el cuerpo electoral que lo ha designado ${ }^{18}$.

adelante, TRC), no 10-11, UNED, Madrid, 2003; TAJADURA TEJADA, J.: Partidos políticos y Constitución, Civitas, Madrid, 2004; ÁLVAREZ CONDE, E.: Derecho de partidos, Colex, Madrid, 2005; CORCUERA ATIENZA, J., TAJADURA TREJADA, J., y VIRGALA FORURIA, E.: La ilegalización de partidos políticos en las democracias occidentales, Dykinson, Madrid, 2008; IGLESIAS BÁREZ, M.: La ilegalización de los partidos en el Ordenamiento jurídico español, Comares, Granada, 2008; TORRES DEL MORAL, A.: «La democracia militante», en VV. AA.: Derecho Constitucional para el siglo XXI, Madrid, 2006, y «Terrorismo y principio democrático», ob. cit.

17 SSTCFA de 23-X-1952 y 17-VIII-1956; la ley electoral de referencia es de 7-V-1956.

${ }^{18}$ Cfr. mi trabajo «Crisis del mandato representativo en el Estado de partidos», RDP, UNED, n 14, Madrid, 1982. 
Hasta ahora, en nuestro Ordenamiento jurídico, los diputados podían conservar su escaño hasta el término de la legislatura y sólo lo perdían por las causas específicamente determinadas en la legislación penal o en los reglamentos de las Cámaras. Pero, cuando en 2003 fue ilegalizada y disuelta Batasuna, el Tribunal Supremo pretendió extender tal disolución a la del grupo parlamentario que dicha formación política había constituido en el Parlamento Vasco. El problema no se ha resuelto aún, pero lo que nunca pretendió el Tribunal Supremo es que los diputados correspondientes perdieran su condición de tales. Ahora bien, esto es precisamente lo que dispone la reforma que estudiamos de la Ley Orgánica del Régimen Electoral General por estimar que, con la llamada incompatibilidad sobrevenida, se ha producido la ruptura de la relación representativa existente entre el cuerpo electoral y los diputados elegidos en las candidaturas del partido ilegalizado. Apenas añadiré, en línea con lo antes precisado, que tal opción del legislador orgánico me parece constitucionalmente incorrecta.

Y lo mismo he de decir para el supuesto de autodisolución del partido político. Si admitiéramos la prevalencia jurídica de un fenómeno político (la democracia de partidos) sobre un principio jurídico-constitucional (el mandato representativo) también en este caso de disolución quedarían los diputados sin el vínculo que los une al Parlamento y al cuerpo electoral, debiendo decaer su mandato. Pero no es así, y no ha sido así en la única ocasión en que pudo presentarse el problema, que fue la autodisolución de UCD en 1983.

\subsection{Inicio y perfeccionamiento de la relación representativa}

La pregunta clave es la de si son los partidos políticos elementos esenciales de la relación representativa.

Hay que tener sumo cuidado con las palabras, equívocas las más de las veces, y ésta es una ocasión muy indicada para estar alerta. Si por elemento esencial entendemos aquel que facilita el proceso, que lo simplifica al reducir a unos pocos los programas en litigio, que clarifica las opciones de gobierno y de control y que después facilita el funcionamiento de las Cámaras mediante unos pocos grupos parlamentarios (o del Ayuntamiento con unos cuantos grupos municipales), la respuesta no puede ser sino afirmativa. Pero si por elemento esencial entendemos uno sin el cual resulta imposible la relación representativa, entonces la respuesta debe ser otra. Porque facilitar no es posibilitar, ni contribuir al funcionamiento de algo es crearlo, ni ser conveniente es igual que ser necesario.

La relación representativa parece — sólo parece- que descansa sobre un triángulo formado por el elector, el partido o formación política que presenta 
candidaturas a la convocatoria electoral y el candidato electo. Los partidos juegan un claro papel de mediadores en esa relación: seleccionan personas capaces, o simplemente obedientes, para conformar las candidaturas, animan las elecciones protagonizando las campañas, presentan los recursos a los que haya lugar y se oponen a los que interpongan las formaciones políticas adversarias. Hablando en términos jurídicos, ejercen una función pública conferida por el Ordenamiento consistente en intervenir y cooperar en varias de las fases del complejo procedimiento jurídico-político que es una elección para facilitar su desarrollo y, por tanto, el funcionamiento mismo de la democracia representativa.

Ciertamente, una función jurídico-pública acaso sea algo más importante que un derecho, pero no es un derecho. Los partidos no son sujetos titulares del derecho de participación política. No ejercen un derecho propio al presentar candidaturas, sino el derecho de los ciudadanos a presentarse, que únicamente por disposición de la ley se articula técnicamente (en algunos países) en candidaturas partidarias cerradas y bloqueadas (en España, en todas las elecciones salvo en las del Senado), atribuyéndosele a los partidos esa función de confección y presentación de las mismas. Y en su intervención en la fase de recursos, se trata del derecho de los candidatos en pugna a su proclamación como electos si procede en Derecho, operación en la que el partido o fuerza política interviene porque ostenta un interés obvio y legítimo, pero no un derecho a tener (?) un diputado más o menos.

Por consiguiente, la función del partido político como mediador no lo convierte en parte de la relación jurídica creada, como tampoco lo es el mediador en una relación jurídico-privada; de manera que, otra vez de forma similar al Derecho privado, si se prescinde de él, no se rompe la relación establecida entre el cuerpo electoral (o la nación, según veremos) y el representante. El nexo jurídico entre ambos no es el partido, sino la elección, el hecho electoral. Si fuera el partido (o la formación política) que presenta la candidatura, su desaparición (por el motivo que fuere: disolución, autodisolución, ilegalización...), llevaría consigo de modo automático la eliminación de la relación representativa por falta de uno de sus elementos esenciales y la consiguiente pérdida del escaño por parte del hasta ese momento representante. Pero no es así.

Por eso he anticipado una cautela acerca de la figura triangular de la relación representativa. De ser ésta su precisa representación gráfica, al faltar un elemento — en nuestro caso, el partido— se destruiría la figura. Su representación más plausible es la de una línea recta dividida en tres segmentos, siendo el central el correspondiente al partido político; si se suprime, se disuelve o se extingue este segmento intermedio por cualquier motivo, los otros dos siguen conectados, ahora más directamente. Un triángulo es imposible de reconstruir con sólo dos lados; 
en cambio, la línea recta aludida se acorta o se simplifica si le falta un tramo, pero sigue siendo una línea recta.

Ejemplos hay muchos en el Derecho comparado y no faltan en el patrio. Recuérdese el ya mencionado caso del partido Unión de Centro Democrático, que se autodisolvió a principios de 1983 sin que decayera la relación representativa del cuerpo electoral con «sus» doce diputados, que siguieron en el cargo y mantuvieron el grupo parlamentario durante toda la II legislatura constitucional (1982-1986). Y esto ha sucedido con relativa frecuencia en los más de ocho mil municipios que hay en nuestro país.

Así, pues, la relación representativa se crea a través de un proceso que se inicia en el momento de la elección (los actos anteriores, incluida la presentación de las candidaturas, son meramente preparatorios) y se perfecciona con la toma de posesión del escaño y juramento de la Constitución por parte del representante una vez cumplidos todos los pasos intermedios, pasados todos los filtros y sustanciados todos los recursos que habilita el Estado de Derecho antes, durante y después de la cita en las urnas; filtros y recursos establecidos precisamente como cautelas para conseguir la pureza del procedimiento, de la subsiguiente relación representativa y del consiguiente ejercicio de la función parlamentaria por parte del elegido.

Superados los pasos señalados, la representación política queda consolidada, adquiere firmeza en Derecho y no debe necesitar reválida alguna cada vez que suceda algo en el país. Lo impide la dignidad del cargo, el respeto a la soberanía nacional que ostenta todo miembro parlamentario y la simple aplicación del principio de conservación de los actos jurídicos y políticos. Por tanto, solamente puede ser alterada (aparte de por la voluntad del representante, que puede dimitir) por el Poder Judicial mediante la condena firme del representante que comporte expresamente la inhabilitación para el ejercicio de cargo público. Pero las hipotéticas tachas que sobrevengan después no pueden ser aplicadas con efectos retroactivos para ilegalizar la elección, sino sólo, en su caso y de modo no automático, con vistas a futuras convocatorias.

Por el contrario, construir jurídicamente la relación representativa haciendo del intermediario un elemento esencial de la misma altera su naturaleza porque es tanto como aceptar que, suprimido ese elemento, se desvanece la relación misma, como si el elector no se hubiera pronunciado en las urnas y como si el diputado no fuera nada por sí mismo, sino una simple pieza suprimible. En esa conexión a tres, el único elemento prescindible en algún momento es el partido: sin el cuerpo electoral, no hay relación representativa; sin el representante elegido, tampoco; sin el partido, sí puede haberla y, si ya la hay, subsistir. 
Lo que decimos de las elecciones al Congreso, acaso pudiéramos decirlo con mayor motivo en las del Senado, las cuales se rigen por un sistema electoral de mayorías y voto personal y en las que, pese a ello, el legislador orgánico, por simplificar y con buen criterio, ha ordenado que sean también los partidos y otras formaciones políticas los que presenten las candidaturas. Pero en realidad no hay en este supuesto un «mayor motivo» porque los diferentes sistemas electorales en nada afectan a las respectivas naturalezas jurídicas de sus actuaciones partidarias y de la relación representativa.

Mejor sería incluir en el protocolo de la toma de posesión, junto al juramento de la Constitución, la condena del terrorismo (y no el mero rechazo o separación, que son conceptos delicuescentes que plantean más problemas de los que resuelven) con mención expresa de los grupos terroristas censados por los tribunales y por las Cuerpos y Fuerzas de Seguridad del Estado, satisfecho lo cual, no se debe volver a exigir nada parecido durante el tiempo de mandato a ningún representante.

\subsection{Razón de Estado y razón jurídica: intransitividad de la ilegalidad}

Si todo lo discurrido hasta aquí es congruente $-\mathrm{y}$ lo contrario habría de ser demostrado con buenos argumentos, no con los habituales_-, la ilegalización de un partido político no viciaría de ilegitimidad la relación representativa en la que medió. Tampoco esa ilegalización de una asociación privada, como es el partido político vicia por sí sola de indignidad e ilegitimidad al miembro de un órgano del Estado ni, menos aún, la composición de dicho órgano tal como en su día quedó establecida electoralmente superando todos los requisitos del Ordenamiento jurídico.

El mediador en una relación no es parte de esa relación. La relación jurídica de la Cámara con las asociaciones animadoras del proceso electoral finaliza justo con esa mediación hasta la próxima convocatoria, si a ello ha lugar, quedando intacta mientras tanto la representación resultante, que, en caso de diputados y senadores, lo es de la nación entera, de la soberanía nacional. No hay, pues, trasvase de ilegitimidad desde el partido político que presenta una candidatura a los miembros de la misma que resulten electos. La indignidad y la ilegitimidad son intransitivas.

Ciertamente, puede suceder — y es lo habitual— que el representante político sea también miembro del partido que lo incluyó en su candidatura. Pero, en tal supuesto, sólo podemos estimar ilegítimo a dicho representante con la correspondiente prueba de su implicación en los hechos imputados al partido o a otros miembros del mismo, en cuyo caso bastaría con actuar contra él para ob-

(C) UNED. Revista de Derecho Político 
tener judicialmente su condena de inhabilitación para el ejercicio de cargo público sin posible extensión a otros colegas en tanto no se pruebe igual implicación de cada uno.

Así entendido el problema, la medida adoptada por la reforma legal que analizamos presenta fisuras no sólo en su consistencia teórica, sino también en su futura eficacia práctica. Así, por ejemplo:

a) Episodios terroristas puede haber más de uno a lo largo de la legislatura. ¿Tendrá el representante «sospechoso» que rechazar el terrorismo todas y cada una de las veces en que esto suceda? ¿No será mejor que todos los representantes políticos rechacen el terrorismo y otras lacras una sola y definitiva vez en el acto de toma de posesión?

b) El partido político «sospechoso» por motivos de terrorismo puede optar por no registrar como afiliados a quienes piensa presentar en sus candidaturas y, en cambio, hacerlo con quienes, por considerar menos valiosos para su política, no va a incluir en ellas. Dichas candidaturas tendrían, por tanto, toda la apariencia jurídica de estar integradas únicamente por independientes, todo un juego de estrategia a la que no se debe dar lugar, pero, si sucede, un Estado democrático de Derecho no puede atajar por la vía de recortar las garantías que le son propias y de contradecir sus propios principios ${ }^{19}$.

c) Por otra parte, el diputado o concejal que pierde su escaño por no hacer la referida declaración de rechazo del terrorismo, puede, unos meses más tarde, en la siguiente convocatoria electoral del ámbito que fuere, y otra vez como independiente de otro partido todavía no ilegalizado, integrar una nueva candidatura y ganar otro escaño, todo ello sin haber movido un músculo en la dirección deseada por la reforma legal comentada. A no ser que, por no hacer la declaración, se interprete que queda contaminado para siempre, lo que volvería a perecerme jurídicamente incorrecto. ¿Cuántas operaciones de este tipo serán necesarias para que quede falseada su simulación de independencia?

La Ley Orgánica 3/2011, para trasladar la ilegitimidad de un partido o formación política ilegalizada al diputado, senador o concejal, se apoya en una mera presunción que ni siquiera es iuris tantum porque es antijurídica: ni la

19 Ya finalizado este trabajo, se ha producido lo pronosticado en el texto: la izquierda abertzale (a todas luces se trataba de «Sortu», aunque no pudiera constar así por estar ilegalizado) ha incluido en las candidaturas de la coalición denominada «Bildu», dentro de la cual concurre a las elecciones municipales de mayo de 2011 junto a Eusko Alkartasuna y Alternatiba, a personas «sin pasado». Pero el Tribunal Supremo juzgó el caso prescindiendo del examen personal minucioso y apreciando una real continuidad con «Sortu» o con Batasuna pretendidamente camuflada con un mero cambio de estrategia. El Tribunal Constitucional ha actuado del mismo modo, pero con resultado diferente. 
culpa ni la ilegitimidad se presumen y pedir una prueba en contrario para refutar esta presunción conduce al imputado a una antijurídica probatio diabólica.

El Derecho es, dicho muy simplificadamente, justicia más seguridad jurídica. Ésta es un valor instrumental para conseguir la justicia, pero, por eso mismo, muchas veces se antepone (no se sobrepone) a ella para hacerla posible. Ciertamente la justicia no puede quedar hipotecada por una cadena de formalismos enervantes, pero las formas son importantes tanto en el mundo jurídico como en el político, y su relevancia crece justo en el punto de encuentro de Derecho y política, en Derecho constitucional, en el cual las formas son decisivas y no valen los atajos ni las razones de Estado.

Porque la democracia es una delicada obra de arte no siempre compatible con los brochazos. Acabar con el enemigo de la democracia es muy importante, pero no a costa de la propia democracia. Ya sabemos que el delincuente va por delante de las previsiones jurídicas y que el Ordenamiento anda siempre detrás procurando tapar huecos, tras lo cual se reabren otros nuevos porque la delincuencia y la pillería aprovechan sus inevitables intersticios para obtener ventajas ilícitas, máxime si se trata de una banda, como ETA, tan experimentada durante cuarenta años en sortear el Ordenamiento. Pero en esta labor se encuentra con sus propios límites. La respuesta no puede consistir en solucionar a las bravas los problemas porque, como suele decirse en términos coloquiales, junto al agua sucia, se nos puede ir el niño por el desagüe. El Estado de Derecho tiene principios y exigencias, y orillarlos por conveniencia política puede acarrear más problemas de los que se intenta solucionar. La razón de Estado sólo es aceptable cuando es, al mismo tiempo, razón jurídica.

\subsection{Una cuestión de procedimiento}

Por otra parte, dicha ley le da a éste asunto un tratamiento jurídico de expediente administrativo y ha investido de la correspondiente competencia a la Administración Electoral permanente, esto es, a la Junta Electoral Central ${ }^{20}$. En efecto:

a) sin que intervenga ningún otro órgano en ello, la incompatibilidad es apreciada por dicha Administración y surte efecto a los quince días naturales desde que ésta comunique al interesado su causa;

b) la mal llamada causa de incompatibilidad puede quedar sin efecto si el interesado hace la mencionada declaración precisamente ante la misma Administración notificante;

20 Párrafos $2^{\circ}$ a $4^{\circ}$ del nuevo apartado $4^{\circ}$ del artículo $6^{\circ}$ de la LOREG.

(C) UNED. Revista de Derecho Político 
c) si los sucesos se reprodujesen a lo largo de la legislatura, se repetirá igual procedimiento, procedimiento que es también el aplicable a los candidatos llamados a cubrir el escaño vacante, incluidos los suplentes ${ }^{21}$;

e) la autoridad judicial, concretamente la Sala regulada por el artículo 61 de la Ley Orgánica del Poder Judicial, sólo actuará en caso de recurso contra la resolución administrativa.

Ahora bien, estamos ante un derecho fundamental y nunca una sanción administrativa puede privar del ejercicio al titular. La sanción referida es tan grave que únicamente puede ser impuesta por resolución del órgano jurisdiccional (ordinario o constitucional) competente según los casos y tras un proceso con todas las garantías. Por consiguiente, aunque la ley no lo explicita así, la intervención anterior de la Junta Electoral Central no puede ser sino la fase inicial de un procedimiento administrativo que tiene su continuación y resolución definitiva ante los tribunales.

En segundo lugar, en el supuesto de que se tratase de diputados y senadores, esa apreciación administrativa de «incompatibilidad», frente a lo que dice la ley, debe comunicarse a la Mesa de la Cámara correspondiente y la declaración del interesado debe hacerse ante el mismo órgano parlamentario porque se trata de perfeccionar la composición de la Cámara y el mandato de uno de sus miembros; y la decisión adoptada sólo será recurrible en amparo ante el Tribunal Constitucional.

Por tanto, la ley orgánica, al disponer una regulación común para concejales, diputados y senadores, resulta inconstitucional, salvo que se salvara dicho escollo mediante una sentencia interpretativa del Tribunal Constitucional, lo que me parece difícilmente justificable porque el intérprete supremo (oficial) de la Constitución no puede actuar como legislador positivo.

Finalmente, del mismo modo que no es revisable la adjudicación de escaños una vez superados todos los controles indicados y por motivos sobrevenidos, tampoco lo son los actos parlamentarios ni las votaciones habidas en las Cámaras con participación de dichos representantes políticos. Así lo exige el principio de conservación de los actos jurídicos y políticos y lo contrario significaría un caos de inimaginable solución que más valdría no barajar siquiera como posible opción.

\subsection{Convicción moral versus principios jurídicos}

No participo yo del buenismo mayoritario y casi unánime que sostiene que en democracia se pueden defender todas las ideas y que las palabras y las ideas no

21 Apartado $5^{\circ}$ del mismo artículo. 
delinquen. Niego rotundamente que quepan las ideologías xenófobas, ni el discurso del odio, ni las ideas antifeministas, ni las terroristas, ni las que predican cualquier otra forma de violencia (aunque no la practiquen directamente), ni las discriminatorias por razones de religión, etcétera. Y ello aunque sean expuestas pacífica y educadamente en una elegante cena-coloquio convocada por una Academia científica.

Por tanto, puede que, desde los criterios morales con los que cada uno valora lo que ocurre en su derredor, haya cierto consenso de la ciudadanía acerca de la reprobación moral tanto de dicho partido como de las personas incluidas por éste a sus candidaturas. Pero ninguna unanimidad moral puede destruir el principio jurídico antes expuesto: ninguna persona es indigna, pero el Ordenamiento sí puede considerar indignos sus actos y castigarlos con una fuerza coercitiva que no tienen las normas éticas; más aún: una vez cumplida la sanción o condena, se considera pagada la deuda jurídica con la sociedad y con sus conciudadanos, pese a lo cual el Ordenamiento tiene memoria y la activa cuando esa misma persona reitera o reincide en su comportamiento criminal, reproduciéndose el ciclo, del que, reiterémoslo una vez más, nunca puede faltar ese elemento de respeto a la dignidad personal de todos y cada uno de los seres humanos.

En conclusión, parece obvio que la solución que proponemos resulta políticamente insatisfactoria porque puede suceder que, a la postre, quienes acostumbran a vivir extramuros del Ordenamiento y hacen de su vulneración regla de conducta, estén interviniendo y decidiendo en las instituciones y además están logrando, para un grupo terrorista, una financiación con el dinero del Estado, es decir, con el de sus propias víctimas. Pero es la solución jurídicamente correcta conforme al Ordenamiento constitucional español, juicio en el cual hemos de prescindir de lo que, como ciudadanos, pudiéramos entender políticamente conveniente o experimentar como legítimos sentimientos. Por lo demás, si es cierto que esa declaración de condena en la toma de posesión puede ser mendaz, igualmente puede serlo la declaración de rechazo y separación del terrorismo que ahora se les pide tras un atentado.

\section{REPLANTEAMIENTO DEL PROBLEMA: ¿HUBO ALGUNA VEZ MANDATO REPRESENTATIVO?}

Hasta aquí, la opinión jurídica que, conforme al Ordenamiento jurídico español, me merecen las recientes reformas de la LOREG por motivos, respectivamente, de tranfuguismo y terrorismo. Creo oportuno añadir ahora algunas consideraciones con un radical cambio de registro, que responden a la inquietud que 
ya he mostrado en alguna otra ocasión por este instituto. Y he creído conveniente repetir en este epígrafe el rótulo empleado en el trabajo varias veces citado que dediqué a este instituto porque su situación, si ha variado algo, ha sido para empeorar: ¿por qué el mandato representativo sufre tantas vulneraciones, bien por parte del legislador, bien en la práctica política tolerada?; ¿por qué su vigencia es tan controvertida, aunque se multipliquen las declaraciones sobre su centralidad en la democracia representativa?; ¿por qué ha sido siempre un instituto tan inseguro? Y, en conclusión, ¿qué futuro podemos augurarle?

\subsection{Origen y naturaleza del mandato representativo}

Aunque apenas vamos a detenernos en el origen del mandato representativo y sólo haremos algunas precisiones básicas, ya recogidas en un anterior trabajo mío, se comprende que una correcta comprensión de este alumbramiento y ulterior funcionamiento en las democracias liberales sea extremadamente importante para nuestro estudio ${ }^{22}$.

Recordemos que el tipo de representación política generalmente vigente durante el Medievo, denominado usualmente como mandato imperativo, de cuyo concepto hago gracia al lector de puro conocido, evidenció históricamente algunas carencias y disfuncionalidades que motivaron su evolución paulatina hacia lo que hoy llamamos mandato representativo.

En Inglaterra tuvo lugar ese cambio de la mano de una progresiva aceptación de que la relación entre mandante y mandatario era de confianza. Ello sucedió porque, cuando los mandatarios se veían superados por la marcha de las deliberaciones en la Corte debido a una derivación de las mismas acerca de la cual no tenían poderes (esto es, instrucciones, mandato) suficientes, había que suspenderlas hasta recibirlos de sus poderdantes. Para evitarlo, el Rey comenzó a exigir que los mandatarios llevaran amplios poderes para ultimar todos los asuntos. Así, las instrucciones comenzaron a ser cada vez más genéricas y a dejar un mayor margen de actuación a los mandatarios, hasta terminar consistiendo en el encargo de que velara por los intereses del condado, burgo, Universidad, gremio o monasterio; dicho de otro modo: les confiaban tales intereses para que cuidaran de ellos y los defendieran. Como dice JELLINEK, un pueblo tan práctico como el inglés no podía sino poner en duda el valor de tal mandato ${ }^{23}$.

${ }^{22}$ Cfr. TORRES DEL MORAL, A.: «Crisis del mandato representativo...», ob. cit.
23 JELLINEK, G.: Teoría General del Estado, $1^{a}$ edic. cast., México, 2000, pág. 511. 
Fueron, pues, necesidades de funcionamiento de la propia monarquía absoluta las que propiciaron el cambio. Pueden detectarse algunos leves antecedentes del mismo a finales del siglo XV, pero, salvo en Inglaterra, la evolución política durante los siglos siguientes en Europa fue poco favorable a su consolidación. Baste recordar que los Estados Generales no se reunieron en Francia desde 1614 a 1789 .

El Agreement of the People (1647 y 1649) daba ya por supuesto que los representantes tenían la suprema confianza (trust) en orden al cuidado del conjunto. LOCKE utiliza reiteradamente expresiones similares, pero, a mi juicio, no con el alcance que estamos indicando ${ }^{24}$. BURKE, en cambio, perfeccionó la idea cuando, en 1774, escribió a sus electores de Bristol que, como representante de ellos, tenía libertad absoluta y no podía estar ligado por promesas obligatorias: su relación con los representados era de confianza, no de cumplimiento de instrucciones.

A este lado del Canal, encontramos la misma idea en MONTESQUIEU, el cual defiende en El Espíritu de las Leyes que los mandatos sean muy generales para así dar mayor libertad a los representantes ${ }^{25}$. En cambio, ROUSSEAU se mostró totalmente contrario a esta forma de representación política como equivalente a la enajenación de la soberanía popular; el pueblo inglés — dice — se engaña creyéndose libre cuando sólo lo es en el momento de elegir, pasado el cual es de nuevo esclavo, no es nada ${ }^{26}$.

Durante los años revolucionarios CONDORCET y SIEYÈS se pronunciaron en igual sentido que BURKE. El primero, después de varios titubeos por el riesgo que podría significar la independencia total de los representantes, termina asumiendo él mismo tal condición, declarándolo así en la Asamblea Constituyente (1791): «Es conservando la independencia de mis opiniones... como yo me esforzaré a responder a esta distinción tan honorable de la confianza de mis conciudadanos» ${ }^{27}$; y escribiendo a sus lectores de l'Aisne en 1792:

«el pueblo me ha enviado no para sostener sus opiniones, sino para exponer las mías; no se ha confiado sólo a mi celo, sino también a mis luces, y uno de mis deberes hacia él es la independencia absoluta de mis opiniones» ${ }^{28}$.

${ }^{24}$ LOCKE, J.: Segundo tratado el gobierno civil, XI-136 y XIII-149, entre otros pasajes.

${ }^{25}$ MONTESQUIEU: El Espíritu de las leyes, XI, 6.

${ }^{26}$ ROUSSEAU, J. J.: El Contrato social, III, 15.

27 CONDORCET: Manuscritos inéditos; cit. por ALENGRY, F.: Condorcet, guide de la Révolution française, París 1904, reimpresión Ginebra 1971, pág. 490 (cursivas mías).

28 Ibidem, mismo lugar (cursivas mías). 
El segundo hizo de la representación el eje del sistema político que estaba emergiendo: la nación quiere y actúa únicamente a través de sus representantes ${ }^{29}$.

El mandato representativo, nombre con el que se conoce esta fórmula, consistente fundamentalmente en la prohibición de las instrucciones, no sólo ofrecía la ventaja de su mayor funcionalidad, sino que los revolucionarios franceses lo dotaron de una base teórica aparentemente sin fisuras por su conexión con el sagrado dogma revolucionario de la soberanía nacional.

Efectivamente, la lucha de los sectores burgueses inquietos de fines del siglo XVIII por alcanzar una representación política paritaria a la de los estamentos privilegiados fue instrumentada jurídicamente de la mano del principio de soberanía nacional y de esta forma de representación. Como se ha dicho gráficamente, con la Revolución francesa se produce una nacionalización de la representación: si la soberanía es una e indivisible, también lo ha de ser la representación, y si el titular de la soberanía es el pueblo, o la nación, la representación es y no puede dejar de ser representación nacional

La Declaración de Derechos de 1789, la Ley de 22-XII-1789 y la Constitución de 1791 consumaron el proceso consagrando las anteriores ideas, que pasan a ser consustanciales al Nuevo Régimen, además de las consabidas de garantía de la libertad y división de poderes. Por lo que concierne al objeto de nuestro estudio, son fundamentalmente los siguientes:

1) La ley es expresión de la voluntad general, de la soberanía nacional una e indivisible.

2) La unidad e indivisibilidad de la soberanía exige — se decía - que los representantes lo sean de la nación en conjunto y no de sus electores concretos. La nación comienza a ser entendida como una unidad global distinta de los individuos y grupos parciales que la componen ${ }^{30}$.

3) La nación no puede querer ni actuar por sí misma, sino sólo a través de sus representantes. Por tanto, quedan prohibidas las instrucciones y la revocación de los diputados.

4) La conclusión extraída de todo ello por la propia Constitución de 1791, título III, artículo $2^{\circ} .2$, es lacónica y expresiva: «La Constitución francesa es representativa... ${ }^{31}$.

29 SIEYÈS: ¿Qué es el tercer estado?, passim.

30 Operación de largo alcance en la que no podemos detenernos aquí. Cfr. TORRES DEL MORAL, A.: «Democracia y representación en los orígenes del Estado constitucional», Revista de Estudios Políticos, n 203 Madrid, 1975; así mismo «Soberanía nacional y representación en la Constitución española de $1812 », R D P, \mathrm{n}^{\circ} 82$, UNED, Madrid, en prensa.

31 No deja de ser reseñable que una Constitución emplee el término «Constitución» como sinónimo de régimen. 
Es cierto que este resultado sobrepasa con mucho las pretensiones iniciales de los sectores burgueses inquietos, que se cifraban, además de en la paridad representativa con los estamentos privilegiados, en la independencia de los representantes respecto de las presiones locales (que eran preferentemente presiones de la nobleza y del clero) a fin de lograr un Parlamento fuerte precisamente frente a esos estamentos y frente al Rey. El resultado fue trascendental y mucho más ambicioso que el que tuvo lugar en Inglaterra, donde solamente se pretendía un mejor funcionamiento práctico del sistema, por más que ambas vías hayan terminado convergiendo.

No faltaron en todo ello algunas derivas poco justificadas, como la prohibición de revocar a los representantes, que se consideró una consecuencia lógica de la prohibición de instrucciones. Insistiremos sobre ello más adelante, pero lo decisivo fue que así se argumentó, que así pasó a formar parte del eje del funcionamiento del Estado constitucional y representativo, que así se hizo valer en Francia con la ayuda de las armas y de la guillotina, que así se exportó a la Europa continental y que así se ha venido practicando en ella (también, claro está, en nuestro país) durante dos siglos.

\subsection{Separación de elección y representación: Relación representativa y soberanía nacional}

Durante la vigencia del mandato imperativo, la designación del mandatario por el mandante marcaba la representación resultante: el mandante era el titular de la misma en todo momento, con la facultad de revocar al mandatario y designar uno nuevo. Después, triunfante el mandato representativo en la Revolución, una vez que el cuerpo electoral ha elegido representantes, son éstos los que gobiernan. La elección está, sí, en el origen de la representación, pero se agota en la elección misma como procedimiento de selección de diputados, en tanto que la representación es una nueva función política a cargo de quienes tienen la condición de representantes por y desde su elección popular. Por tanto, la primera consecuencia que debemos extraer es la de que, en la pureza del mandato representativo, la operación electoral y la función representativa, aunque unidas en su inicio, quedan finalmente separadas.

La explicación, como hemos visto, reside en que lo representado ahora es la nación, una e indivisible ${ }^{32}$.

32 Dígase lo mismo del concejal respecto del municipio y del diputado autonómico en relación con la Comunidad Autónoma respectiva.

(C) UNED. Revista de Derecho Político 
En las páginas anteriores he venido evitando las más de las veces hablar del elector como uno de los elementos de la relación representativa y he solido optar por el término «electorado» o por la expresión «cuerpo electoral». Ahora es preciso dar un paso más: una vez ultimado el proceso electoral y efectuada la toma de posesión de los escaños, el primer elemento de la relación representativa deja de serlo la persona física, el ciudadano individual que depositó, o no, su voto en la urna; tampoco lo es el conjunto de ciudadanos de cada circunscripción respecto del candidato o candidatos que compitieron en ella, y ni siquiera lo es el cuerpo electoral, ya que éste está integrado únicamente por las personas con derecho de sufragio activo. Lo es la nación entera. (No es necesario recordar que en el Nuevo Régimen se produjo una verdadera nacionalización de la soberanía y de la representación.)

La conclusión que se extrajo fue la de que ni los electores individualmente considerados, ni un grupo o varios de ellos, ni el electorado de una o varias circunscripciones tomados en su conjunto podían dar instrucciones a los representantes de la nación. Y la nación tampoco lo hace porque su cometido termina, salvo disposición constitucional en contrario, con su participación electoral (o, en su caso, referendal); de ahí en adelante, la nación únicamente quiere y actúa, como decía SIEYÈS, por medio de sus representantes. Y, si no hay instrucciones, no puede haber incumplimiento, sino independencia de actuación y, por tanto, irrevocabilidad.

Esta mutación es realmente una novación: los sujetos que contactan a través del proceso electoral son el conjunto de electores de la circunscripción correspondiente y los candidatos. Ambos ejercen un derecho fundamental, reconocido entre nosotros en el artículo 23 del texto fundamental. Pero, una vez perfeccionada la elección, se produce una novación de la relación representativa, que pasa a ser otra que la trasciende y con dos sujetos diferentes de sus originarios partícipes: la existente entre la nación y el Parlamento.

Por eso el artículo 66 de nuestra Constitución dice que las Cortes Generales representan al pueblo español y no lo dice de cada una de las dos Cámaras, menos aún de los diputados y senadores. Bien es verdad que, como hemos expuesto anteriormente, en cuanto órganos y miembros integrantes de las mismas, se considera que tanto el Congreso como el Senado, por separado, ostentan igual representación, y también —aunque en un principio el Tribunal Constitucional titubeó al respecto — los diputados y senadores individualmente considerados. Pero, en puridad, tanto aquéllas como éstos son representantes del pueblo español no por sî mismos, sino en cuanto integrantes de las Cortes Generales.

Los estudios sobre esta materia no han reparado en algo que, siendo una mera curiosidad, no deja de ser interesante: las Constituciones de países demoliberales no suelen referirse a este modelo de representación política ni por su reconocido 
nombre ni de forma directa, sino por referencia al modelo anterior, el mandato imperativo, bien de modo negativo, prohibiéndolo, bien oblicuamente, desvinculando del mismo a los parlamentarios.

- «Todo mandato imperativo es nulo» (art. 47.1 de la Constitución francesa).

- «Cada miembro del Parlamento representa a la Nación y ejerce sus funciones sin vínculo de mandato» (art. 67 de la Constitución italiana).

- «Los miembros de las Cortes Generales no estarán ligados por mandato imperativo» (art. 67.2 de la Constitución española).

- «Los miembros del Consejo Nacional... no estarán ligados a mandato ni instrucciones, sino solamente a su conciencia» (art. 38.1 de la Ley Fundamental alemana).

En cambio, la Constitución portuguesa silencia este extremo y, aunque en el artículo 153.2 se alinea con el principio de representación nacional («Los diputados representan a todo el país y no a las circunscripciones en las que hayan sido elegidos»), el artículo 163 dispone:

«1. Pierden el mandato los diputados: c) Que se inscriban en un partido distinto de aquél por el cual se presentaron a las elecciones».

\subsection{El instituto de la revocación}

La construcción real y efectiva del mandato representativo adolece de varios vicios bien visibles. Nos vamos a referir, muy brevemente, a la desaparición de un elemento de la relación representativa anterior: la revocación.

Como sabemos, el mandato imperativo consistía en las instrucciones de obligatorio cumplimiento que los mandantes daban a sus mandatarios y la revocación era una consecuencia jurídica de la existencia de instrucciones y de su conculcación, o bien del juicio libérrimo de los mandantes. En cambio, en el Nuevo Régimen los representantes no son meros comisionados ni portavoces, sino que su estatuto jurídico está informado por el principio de independencia de toda posible injerencia ni mandato exterior. Pero en este modelo también cabe, aunque no parece que nos dirijamos a ello, la revocación del representante, no por el partido político, ni por el grupo parlamentario, ni siquiera ope legis, sino por parte de quien le otorgó la representación, que es el cuerpo electoral, o mejor, la nación.

En efecto, sustituidas las instrucciones por la confianza, la revocación puede insertarse en el mandato representativo por el deterioro o la pérdida de la confianza

(C) UNED. Revista de Derecho Político 
que el cuerpo electoral, la nación, depositó en los representantes. Es ante ésta donde se debe dirimir si el representante se ha apartado del programa inicial y, en caso de haberlo hecho, si ello fue con razón o sin ella; es la nación (o, a los efectos funcionales, su correspondiente circunscripción electoral) la única que puede apreciar si su comportamiento en la Cámara adolece de impericia, absentismo o carácter contradictorio y errático, o bien si su implicación en causas de corrupción o en otros motivos similares lo hacen desmerecer de la confianza política que le otorgó ${ }^{33}$.

El mismo Tribunal Constitucional no se muestra contrario a esta tesis. Aunque sea como obiter dicta, se extendió en consideraciones afines ${ }^{34}$. En el derecho de acceso a los cargos — dice- no sólo se ventila el de los representantes a mantenerse en el mismo, sino también la efectividad del derecho de participación de los ciudadanos a través de aquéllos (art. 23.1), que se vería defraudado si pudieran ser cesados por una voluntad distinta de la del electorado, y, eventualmente, de la propia voluntad del elegido, que conserva siempre, naturalmente, su derecho a dimitir. No es constitucionalmente legítimo, por tanto, que los representantes puedan ser privados de su función por una decisión que no emane de los propios electores. Podrá discutirse la conveniencia o la licitud de la revocación por parte de los electores, pero no cabe la revocación por instancias distintas. Dicho de otro modo: los representantes, una vez elegidos, lo son de la nación, y titulares de una función pública a la que no puede poner término ningún poder que no sea el de la voluntad popular ${ }^{35}$.

A lo que se ve, el Tribunal no estima frontalmente ilícita la revocación por parte de los electores, sino la proveniente de los partidos políticos. Acaso sin advertirlo, puso las bases para la admisibilidad de la revocación como una consecuencia de la elección: cuando exceptúa el puesto de Alcalde de la irrevocabilidad de los cargos representativos, dice que, como es elegido por los concejales, éstos pueden destituirlo. Trasladando este planteamiento a los concejales, la conclusión se extrae directamente: como los concejales son elegidos por los vecinos, éstos podrían revocarlos, aunque no lo diga así expresamente la ley.

33 Si bien miramos, algo parecido, mudando lo mudable, sucede en la moción de censura: los parlamentarios, que invisten a un Presidente del Gobierno con un programa-compromiso, no están obligados a cesarlo porque lo haya incumplido y pueden hacerlo aunque lo haya cumplido.

34 SSTC 5, 10, 16, 20, 28, 29 y 30/1983, y 28/1984, citadas.

35 El Tribunal parece olvidar la facultad que tiene el Ejecutivo de disolver una o las dos Cámaras (art.115 de la Constitución), pero es cierto que tal instituto no tiene encaje en el problema que estamos diseccionando. 
La inserción de esta mueva pieza en el sistema es delicadísima, técnicamente muy difícil y acaso presentara más inconvenientes que ventajas. Eso es cierto. Pero también lo es que en ningún momento se ha intentado, de manera que la conclusión sigue en pie, al menos en un horizonte teórico de posibilidades. Por muy difícil que sea su articulación técnica y por muy políticamente inconveniente que sea para muchos, no deja de ser una opción constitucionalmente válida, porque es compatible con el sistema ${ }^{36}$.

\subsection{Un sistema de representación abocado a la parálisis y a su necesario falseamiento}

Por eso, volviendo a los orígenes, a la Francia de 1789 o a 1791, y sin mengua de reconocer la enorme diferencia entre el absolutismo y el constitucionalismo y de sentirnos muy afortunados de estar instalados en éste, se me concederá que la perspectiva abierta por el nuevo sistema de representación política no era muy satisfactorio. Imaginemos el resultado más lógico del recorrido que hemos hecho por las ideas (mejor, dogmas) que revolucionaron el mundo e iniciando no sólo un Nuevo Régimen, sino una Nueva Era. No reparemos ahora en el funcionamiento del sistema representativo en las democracias actuales, que ése es bien conocido, sino en el que, en orden a los principios, se habría correspondido con la nacionalización de la representación política llevada a cabo por la Revolución. El sistema habría adoptado un perfil parecido a éste:

a) Unos electores que, con su voto en las urnas, depositan su confianza en todos los candidatos elegidos, aunque no los hayan votado, y quedan separados de toda relación efectiva con ellos desapareciendo del escenario político hasta la siguiente convocatoria. Bien es verdad que, al principio las legislaturas tenían una más corta duración (dos años o incluso uno sólo) que las actuales.

b) Unos elegidos y un Parlamento que representan a la nación entera y sólo a ella se deben. El Parlamento, en cuanto tal, ejercía la soberanía nacional. Era el templo de la razón y de la palabra, cuyo funcionamiento, en teoría, requería que los diputados acudieran a él sin instrucciones de ningún tipo, desprovistos de prejuicios, de intereses y de votos decididos, prestos a debatir con sus colegas legisladores, a votar

36 Su existencia y mermada práctica en el sistema político de la URSS y de los países satélites (principalmente en el ámbito local) no ha contribuido precisamente para que este instituto lograra una opinión favorable en los regímenes demoliberales.

(C) UNED. Revista de Derecho Político 
en conciencia lo que cada uno creyera mejor para el interés nacional, a aceptar el resultado de la votación como el mejor, e incluso a defenderlo en su distrito electoral como el mejor posible, dado que era producto de la voluntad general.

c) Unos cuerpos intermedios (asociaciones, gremios...), tan necesarios según MONTESQUIEU, tan abominables para ROUSSEAU y tan eliminados por la Revolución, que en esto fue más rusoniana que montesquiniana. El derecho de asociación no fue introducido en los ordenamientos jurídicos hasta avanzado el siglo XIX y los partidos políticos fueron, primero, prohibidos y después, ignorados (TRIEPEL).

d) Unos intereses sociales sectoriales (de los ciudadanos de una provincia o de un municipio, de los pertenecientes a una profesión determinada, los de un sector económico, los de los trabajadores, los de los empresarios y los de un etcétera tan amplio como se quiera) que carecen, por tanto, de cauces institucionales de expresión y defensa ante los poderes públicos y que quedan mágicamente asumidos, conjugados, atendidos, defendidos y realizados, es decir, sublimados en y por el interés nacional.

e) Unos eventuales desacuerdos de la nación con la actuación de los representantes políticos, bien por su reducida inteligencia y habilidad, bien por su negligencia, bien por su tendencia a defender como interés nacional sus intereses particulares de banqueros, terratenientes, aristócratas o políticos profesionalizados; desacuerdos que, salvo el «castigo» de una opinión pública adversa (de ahí la extraordinaria función política de la libertad de comunicación pública, uno de los bienes más preciosos del hombre, según la Declaración de Derechos de 1789), no tienen ninguna traducción jurídica, quedándole a la nación la única arma — política y aplazada — de esperar a la siguiente convocatoria electoral para aplicar a tales representantes el correctivo pertinente de la no reelección.

Conforme escribo estas líneas no puedo sino recordar el tratamiento que da ROUSSEAU a la cuestión de la conciliación de las voluntades particulares con la voluntad general en su modelo político ideal. Recordemos: como todos los ciudadanos saben ya distinguir entre l'amour propre y l'amour de soi, la elección de mandatarios resultará necesariamente correcta, y las instrucciones, adecuadas a los intereses de la comunidad; y como, por otra parte, también los mandatarios saben diferenciar entre la volonté de tous y la volonté générale y saben además que ésta es infalible, acudirán a la Cámara con una única arma política: su limpia conciencia, desprendida de todo prejuicio y de toda inclinación personal por una solución u otra para el problema que se esté dilucidando, por lo que está sinceramente 
dispuesto a votar en conciencia y acepta la solución mayoritaria como voluntad general infalible y justa ${ }^{37}$.

El modelo es teóricamente impecable, pero, ¿dónde se encuentra el país real en el que se dan esas condiciones, se hayan dado o sea previsible que se den en el futuro? Naturalmente en ninguna parte, ni siquiera durante la Revolución en Francia. Pero eso a ROUSSEAU, de haberlo vivido, no le habría preocupado: él teorizaba sobre cómo deberían ser las cosas si el contrato social inicial hubiera sido correcto, es decir, igualitario. Tenía razón. Pero el problema político consiste en arreglar este mundo sin necesidad de volver a andar a cuatro patas para empezar de nuevo, como le reprochaba VOLTAIRE con ácida ironía. Por eso, cuando ROUSSEAU aceptó — primer error- el más prosaico encargo de hacer recomendaciones constitucionales a los corsos (Proyecto de Constitución para Córcega) y a los polacos (Consideraciones sobre el gobierno de Polonia y sobre su proyectada reforma), se contradice continuamente intentando poner parches en la realidad política que tenía como materia moldeable, porque, como él mismo había escrito en el Contrato social, su teoría política exigía empezar de nuevo, sin las desviaciones e injusticias consolidadas en la sociedad, digamos, civilizada, desviaciones e injusticias debidas a una educación, una cultura, una religión, un Derecho, una moral, y un arte productos de la desigualdad entre los hombres, y causa, a su vez, de la reproducción y perpetuación de esta misma desigualdad ${ }^{38}$.

(Discúlpeseme la introducción en un modesto paréntesis de una nota referente a Inglaterra y demasiado pertinente como para llevarla al habitualmente ignorado pie de página; la hago con el propósito de volver de inmediato al Continente. Inglaterra, cuya aportación al constitucionalismo parece ser no sólo la del modelo de la monarquía parlamentaria, sino también servir de permanente excepción a la teoría general, es otra vez diferente, ahora por un motivo bien relevante: el funcionamiento del sistema sobre partidos políticos caracterizados por: a) no ser ni clandestinos ni meramente tolerados, sino protagonistas indiscutidos de los procesos electorales; b) ser partícipes de una ordenada alternancia política, cada vez más dependiente de los resultados de las elecciones y menos de la voluntad del monarca; c) que, contra lo que podría esperarse del país que dio el primer paso hacia la relación de confianza, practicaban la disciplina de voto en las Cámaras, sustituyendo indisimuladamente una disciplina por otra. Dos versiones

37 ROUSSEAU, J. J.: El contrato social, II, 3 y IV, 2.

38 Me he ocupado de la teoría política de ROUSSEAU, precisamente desde la perspectiva de la contraposición de su modelo de contrato social con el antimodelo de contrato que subyace bajo la sociedad real histórica de su tiempo, en «Modelo y antimodelo en la teoría política de Rousseau», Revista de Estudios Políticos (en adelante, REP), nº Madrid, 1977.

(C) UNED. Revista de Derecho Político 
muy diferentes del sistema representativo jurídicamente basado en la relación de confianza, que, no obstante, han terminado convergiendo, como veremos en el apartado siguiente. Pero esto ha sucedido por el falseamiento de una de ellas.)

\subsection{Los partidos políticos ocupan el vacio del sistema. Hacia el mandato imperativo de partidos}

En realidad, independientemente de los magnos servicios aportados, la Revolución creó un páramo en el terreno que estamos estudiando, un vacío político tan enorme entre la ciudadanía y los productos de la voluntad general, con tales las carencias teóricas y dificultades prácticas que estaba abocado a su parálisis. De ahí que no haya funcionado tal cual en ningún lugar ni tiempo. Y, como tanto en la naturaleza como en la política existe un horror vacui, el sistema fue falseado desde su nacimiento contraviniendo sus propios principios.

Porque, clandestinas o toleradas, había asociaciones, como había gremios, y también partidos políticos, en forma de comités electorales, todavía poco formalizados y menos consolidados, pero ideológicamente diferenciados, tanto en Francia como en España en el periodo gaditano ${ }^{39}$, por no hablar de Inglaterra y de Estados Unidos, y con programas políticos, aunque fueran elementales; comités y fuerzas políticas de hecho que prolongaban su actuación en la Cámara con alineaciones o agrupamientos de diputados en la Asamblea Nacional, que fueron los embriones de los grupos parlamentarios ${ }^{40}$. Éstos actuaban lógicamente en pro de sus propios intereses y con los votos previamente decididos, incluso a veces sometidos a unas presiones que la prudencia aconsejaba atender, como se demostró, si es que hacía falta, en la votación sobre la condena a muerte de Luis $\mathrm{XVI}^{41}$.

Los ordenamientos jurídicos tardaron más de medio siglo en reaccionar y amueblar ese fantasmal edificio permitiendo la actuación pública de algunas organizaciones sociales como asociaciones de hecho, al abrigo de las cuales actuaron los partidos, que fueron meras fuerzas de hecho durante siglo y medio. La insti-

39 En Francia, girondinos y jacobinos; poco después, en las Cortes gaditanas, los diputados se alineaban tanto por su ideología cuanto por su procedencia metropolitana o ultramarina; y, durante el trienio liberal, radicales y serviles.

${ }^{40}$ La distinción entre derecha e izquierda procede precisamente, como es de sobra conocido, de la práctica parlamentaria de la Revolución.

41 Prescindo de la crónica negra, con persecuciones, asesinatos y bárbaras ejecuciones de los enemigos políticos por parte de quienes tenían el monopolio de la guillotina. 
tucionalización jurídica de los grupos parlamentarios, aunque tardía, fue anterior a la de los partidos, que hubo de esperar casi un siglo (y más en algunos países, como el nuestro). Poco a poco los partidos fueron legalizados y últimamente, ya en la segunda posguerra mundial (salvo excepciones anecdóticas), constitucionalizados.

Al compás de esta progresiva institucionalización, se fue aceptando su relevancia electoral. Los partidos protagonizan el inicio de la relación representativa, y como, hablando en términos jurídico-formales, desaparecen de dicha relación, no pueden dar instrucciones a «sus» parlamentarios y les confían los intereses del partido. Mantienen con ellos un vínculo asociativo que puede romperse en cualquier instante, ora por mutuo acuerdo, ora por expulsión del parlamentario por parte del partido, ora por decisión unilateral del parlamentario, ora por resolución judicial; y, sin embargo, como el partido no forma parte de la relación representativa, los parlamentarios elegidos en sus candidaturas no pierden sus cargos en tales supuestos.

Por otra parte, se ha producido la inevitable conexión entre los partidos y los grupos parlamentarios ${ }^{42}$, bajo cuya veste actúan aquéllos en las Cámaras. Los grupos parlamentarios se suelen constituir según normas reglamentarias de las Cámaras, los cuales que buscan y favorecen su correspondencia con los partidos políticos en cuyas candidaturas fueron elegidos sus miembros parlamentarios, aunque no tanto que impidan la constitución de uno diferente o la inscripción del diputado o senador en el Grupo Mixto o como no inscrito.

En seguida se convirtió en práctica tolerada la disciplina de voto, con lo que se vulneraba el Ordenamiento para que el sistema funcionara. Porque, si bien es cierto que el diputado o el concejal pueden no seguir las instrucciones, más bien órdenes, del partido, no menos cierto es que la vulneración jurídica se produce con la emisión misma de la orden de votar en determinado sentido, aunque finalmente sea desoída. No hay noticia de que se haya sancionado nunca, ni siquiera investigado, a un grupo parlamentario o a un partido político por haber hecho pública su instrucción u orden de voto. Tal práctica se pone de manifiesto clamorosamente cuando un grupo parlamentario o incluso el partido político de referencia conceden libertad de voto (!) con ocasión de cierta ley o decisión.

42 Se trata de dos instituciones políticas diferentes: el partido actúa sobre la sociedad, el grupo parlamentario en la Cámaras legislativas; y no siempre se corresponden puesto que hay partidos que no logran presencia en el Parlamento y no todos los que lo logran pueden constituir «su» grupo parlamentario. Pero, por lo general, sí se da esa correspondencia, siendo el grupo parlamentario la correa de transmisión del partido político en el Parlamento (G. U. RESCIGNO); cfr. mi trabajo «Los grupos parlamentarios», RDP, n 9, Madrid, 1980.

(C) UNED. Revista de Derecho Político 
Así, pues, este acentuado y progresivo protagonismo de los partidos en todo el funcionamiento del sistema político, y muy decididamente en las elecciones y en la vida de las Cámaras, ha facilitado e incluso propiciado su interferencia y omnipresencia en la relación representativa aportando a la misma las instrucciones que ni el elector ni la nación misma pueden dar. Y, por otra parte, como los partidos tienen el cuasi monopolio de la presentación de las candidaturas, el parlamentario indisciplinado se verá «expulsado» de las candidaturas subsiguientes (formalmente, será «no incluido» en ellas); esta exclusión equivale, no jurídicamente, pero sí políticamente, a una revocación a término.

Tal posición de privilegio del partido a la hora de componer «sus» candidaturas, permite la selección de unos diputados y concejales sumisos y obedientes que apenas intervienen en la Cámara durante toda la legislatura y cuya contribución al funcionamiento del sistema se limita a votar lo que les indica su partido, si es que, acaso sumidos en profundas reflexiones sobre la responsabilidad que los embarga, no se equivocan y votan lo contrario.

Todo ello contradice la idea inicial del Parlamento liberal como templo de la razón y de la palabra y permite la formación de una «clase política» profesionalizada, a la que en ocasiones se la percibe más atenta a sus propios intereses como tales profesionales que al bien común. Pero, en aras de la verdad, también es cierto que libera al Parlamento, al menos parcialmente, de políticos dilettantes, dados a lo que la doctrina italiana ha bautizado como «alquimia parlamentaria», con espontáneas alineaciones contra natura y mercadeo de votos.

En un momento anterior hemos concluido que, en la pureza del modelo, al cuerpo electoral no le cabía, en caso de disconformidad con el ejercicio de la representación por parte de candidato elegido ninguna arma jurídica, sino política y aplazada: la no reelección del representante que lo ha defraudado. Sin embargo, en la práctica política real de la democracia de partidos, puede que ni siquiera le sea accesible esa oportunidad de manifestar con su voto ese reproche político a los representantes indeseados debido a que el sistema electoral ha impuesto en algunos países (el nuestro entre ellos) candidaturas colegiadas, cerradas y bloqueadas, en cuyo caso no cabe sino «castigar» al partido que, pese a todo, sigue incluyéndolos en sus candidaturas.

En una palabra: la posición que en el Antiguo Régimen tenían los señores feudales, abades, gremios, etc., como titulares — más bien «dueños»— de la representación, la han asumido los partidos en los regímenes demoliberales. Con una diferencia todavía, y hay que reconocer que de no escasa relevancia: de momento, la titularidad jurídica del escaño pertenece al diputado y éste puede, en cuanto representante de la soberanía nacional, plantar cara a «su partido», votar en contra de sus instrucciones y mantenerse en el escaño hasta el final de la le- 
gislatura. Eso equivale a poner en juego su carrera política y no lo hace casi nadie, es cierto, pero puede hacerlo. Estamos solo a un paso del mandato de partidos.

\subsection{Representación e identidad}

En la democracia de partidos se ha perdido o difuminado «el representante con personalidad influyente en su distrito y transmisor de demandas de sus electores», en palabras de M. GARCÍA CANALES. Esta relación un tanto simple (y acaso simplista, por cuanto más bien describe un modelo teórico que el funcionamiento práctico del régimen liberal) ha sido sustituida por otra mucho más compleja en la que, a su vez, siguiendo libremente al autor citado, pueden identificarse varias:

1) La existente entre el candidato (y, a fortiori, el representante ya elegido) y el partido político, «una relación de fidelidad y de subordinación, incluso de mandato imperativo».

2) La que se establece entre el elector (al menos, el elector de voto estable) y el partido, que ha venido a sustituir la del elector con el elegido. Este fenómeno queda potenciado en países, como España, con sistemas electorales proporcionales y candidaturas cerradas y bloqueadas, en las que «la omnipotencia del partido queda sin ningún contrapeso eficaz» ${ }^{43}$. Estamos más bien ante la identificación de ese elector con «su» partido, aunque no sea militante del mismo.

3) La más reciente y pujante que se crea entre ese mismo elector y el líder del partido cuya candidatura suele votar.

Esta última ha venido determinada por la propia dinámica del sistema, que ha derivado hacia la concentración de la imagen del partido en la figura de su líder y candidato a la Presidencia del Gobierno (del ámbito territorial que fuere). Así se organizan las campañas electorales. «En vez de elegir parlamentos se plebiscitan líderes». De tal manera que el sistema representativo adquiere tintes plebiscitarios y «el principio representativo toma rasgos del principio de identidad». El líder triunfante en las elecciones adquiere legitimidad «no sólo frente a otros líderes, sino, incluso, frente a su propio partido».

Pues bien, los ordenamientos jurídicos, igual que antaño funcionaban sobre asociaciones de tinte político y más adelante sobre partidos políticos propiamente

43 GARCÍA CANALES, M.: «La huella presidencialista en el constitucionalismo español», Revista Española de Derecho Constitucional, no 44, Madrid, 1995, págs. 120-127.

(C) UNED. Revista de Derecho Politico 
dichos, pero los silenciaba, como si el sistema funcionara sin ellos, ahora, salvo excepciones, se dedican a introducir correcciones en el funcionamiento práctico del sistema sin poner en cuestión su fundamento, que permanece idéntico, o casi, al modelo de representación de BURKE y CONDORCET, ese modelo que, como hemos expuesto, nunca funcionó como tal. Pero, como se trata de medidas que responden a un fundamento diferente, que podríamos entender como un cierto principio de identidad, no siempre encajan bien en el sistema corregido y frecuentemente se instalan en el borde de la constitucionalidad, las más de las veces por fuera.

No obstante, hasta ahora, la última relación descrita no ha sido puesta en juego con pretensiones jurídicas en ningún régimen demoliberal ni, por supuesto, en la reciente reforma electoral española, motivo por el cual ni la hemos analizado en las páginas que anteceden ni la tomamos en consideración en las que ponen punto final a este trabajo.

\section{DE NUEVO CON LA REFORMA ELECTORAL ESPAÑOLA}

\subsection{El mandato de partidos, a la vista}

El penúltimo intento en nuestro país, bien que con precedentes en el Derecho comparado, de fortalecer la posición de los partidos a costa de la independencia de comportamiento de los representantes individuales en las instituciones es el tendente a evitar o dificultar al máximo el fenómeno del transfuguismo, al que hemos dedicado unas páginas precedentes. Y el último es el que dispone la pérdida del escaño por parte del representante político siguiendo la suerte de «su partido» si éste es ilegalizado.

Estas reformas atribuyen a la inclusión de una persona en la candidatura de un partido político el efecto jurídico de la vinculación a ese partido una vez elegida en sus candidaturas como diputado, senador o concejal. Hasta tal punto es esto así que, según hemos visto, cierta indisciplina partidaria del representante, como es la decisión de firmar una moción de censura contra el Alcalde de su partido, es disuadida e incluso matemáticamente esterilizada en muchos casos; y, de otro lado, si el partido desaparece por ilegalización motivada por connivencias terroristas, también desaparece la representación de los diputados, senadores y concejales; incluso antes de la ilegalización también pueden perder el escaño si no se desvinculan expresa e indubitadamente del motivo terrorista en que se apoya una demanda de ilegalización. 
Todo ello equivale de una manera bastante evidente, bien que no formulada expressis verbis, a acoger en nuestro Ordenamiento un cuasimandato mandato de partidos. En esta operación se parte de la presunción de que la inclusión en la candidatura que presenta el partido hace al representante dependiente de éste y de que su función en la Cámara consiste casi exclusivamente en cumplir sus instrucciones o mandatos, presunción que, hoy por hoy, es inconstitucional, pero la legislación infraconstitucional va cumpliendo paso a paso la demolición del mandato representativo y su sustitución por este mandato de partidos.

Decíamos hace un momento que todavía queda la vigencia formal del mandato representativo y la independencia, también formal, de los representantes individuales. Sin embargo, la reforma electoral que comentamos le da un tajo a esta última reminiscencia de la representación nacional y da un paso más hacia la «normalización» jurídica del mandato imperativo de los partidos sobre «sus» representantes electos. La simple obligación de éstos de declararse independientes y rechazar un determinado suceso es prueba irrefutable de que el Ordenamiento no los considera tan independientes y que condesciende con la vigencia formal del instituto haciendo como que se conforma con tal declaración, pero colocándolos bajo sospecha hasta el término de la legislatura.

\subsection{Consideraciones finales: el porvenir de la reforma}

Todo el ejercicio dialéctico que antecede no pretende otra cosa que la puesta en evidencia de que un principio tan importante como el del mandato representativo, que es seguramente el principio funcional básico sobre el que se erigió y todavía se apoya formalmente la democracia representativa, sigue estando muy necesitado de una sólida fundamentación jurídica, de la que siempre anduvo un tanto ayuno. Por eso, su funcionamiento ha sido siempre deficiente y, como estamos comprobando, parece batirse en retirada, siendo la reforma legal que estudiamos un buen exponente de ello.

En función de lo cual estimo que pueden extraerse las siguientes consideraciones finales:

$1^{\mathrm{a}}$. Ni el Parlamento liberal ni el mandato representativo han sido lo que la «teoría oficial» decía que era:

a) El Parlamento nunca fue el templo de la razón y de la palabra incontaminado de realidad exterior; antes al contrario. Y en la actual democracia representativa se nutre de una «clase política» cooptada por los partidos y adscrita a ellos, más atenta a los intereses partidarios que al bien común. 
b) Dadas las carencias del mandato representativo desde su gestación, no deben extrañar ni su falseamiento durante dos siglos ni las iniciativas formales e informales para corregirlo. Su superación por un mandato de partidos es cuestión de (no mucho) tiempo, aunque debería hacerse siempre por vía ortodoxa, esto es, con la preceptiva reforma constitucional y con puntería afinada para no crear más problemas de los que se quieren resolver. No obstante, a la vista de la evolución de los regímenes demoliberales, creo que, al menos en la mayoría de los casos, se preferirá la vía indirecta y un tanto torticera seguida hasta ahora y que, cuando no quede nada del instituto en cuestión, se lo podrá rematar — nunca mejor dicho- bien con la reforma aludida, bien mediante la apreciación jurisprudencial de que se ha producido una mutación constitucional y que las Constituciones ya no dicen lo que decían.

$2^{\text {a }}$. Por lo que al objeto de nuestro estudio concierne, es cierto que el artículo 23.2 de la Constitución remite a la ley (orgánica) la regulación del ejercicio del derecho de participación política y de acceso a los cargos públicos. Pero, aunque esto hace de él un derecho de configuración legal ${ }^{44}$, no contradice su naturaleza constitucional, fundamental e incluso central en el régimen constitucional representativo. Por tanto, aunque el legislador goza de un amplio margen para la regulación de este derecho, no puede introducir limitaciones ni requisitos que desnaturalicen la representación ${ }^{45}$, como son, a mi juicio, los que hemos estudiado.

En efecto, la reciente reforma electoral española se ha limitado a introducir medidas pretendidamente justificadas por la defensa de la limpieza y de la libertad del proceso democrático. Esto último no es del todo incierto, pero eso no valida cualquier intento jurídico de conseguirlo. Más bien se trata de unos parches para tapar sendos agujeros, parches que, por ser de distinto material que el tejido que pretenden curar, probablemente lo perjudiquen.

En el problema del transfuguismo, son los partidos los que tienen que seleccionar bien a los miembros de las candidaturas y no por sus nombres, por su popularidad o por otro tipo de oportunismo; si se equivocan, tendrán que aguantar el resto de la legislatura y, dado que los ordenamientos les conceden el monopolio de la presentación de las candidaturas, seleccionar mejor a los candidatos en la próxima ocasión antes de que se produzca el perfeccionamiento de la relación representativa.

En el caso del terrorismo, la sentencia ilegalizadora de un partido o fuerza política sólo puede tener efectos de cara al futuro. Como he admitido en páginas an-

\footnotetext{
${ }^{44}$ Cfr. STC 25/1990, de 16 de febrero.

45 Cfr. SSTC 10/1983 y 75/1985, citadas.
} 
teriores, comprendo que esta solución es políticamente muy insatisfactoria por cuanto permite la prolongación de la vida de una fuerza política ilegal. Pero es la única constitucionalmente aceptable. Los poderes públicos son los que deben tomar buena nota para seguir estableciendo controles previos hasta depurar la idoneidad democrática de los representantes, pero aceptando democráticamente que los que logren pasar todos los filtros tienen derecho a cumplir su mandato por el tiempo constitucional o legalmente establecido, salvo error en los hechos, y procurar afinar mejor en el futuro.

$3^{\text {a }}$. La reforma analizada puede ser calificada de dos modos:

a) Como contradictoria en sus dos vertientes (transfuguismo y terrorismo) con el modelo de representación formalmente vigente en la Constitución y, por ende, inconstitucional.

b) Como un paso más, con precedentes importantes en Derecho comparado, en la superación del modelo de mandato representativo, constantemente rectificado en sus dos largos siglos de vigencia formal y mediocre eficacia. Significa un paso más hacia la «normalización» jurídica del mandato imperativo de los partidos sobre «sus» diputados, senadores y concejales. Pero se ha instrumentado jurídicamente de modo erróneo y deficiente.

$4^{\mathrm{a}}$. Esta demolición del mandato representativo y su avanzada sustitución por el mandato de partidos se pone de manifiesto al atribuir a la inclusión de una persona en la candidatura de un partido político el efecto jurídico de su vinculación a éste una vez elegida como representante, hasta el punto de que no puede censurar a su Alcalde y, si el partido desaparece por ilegalización, debe cesar en su cargo, salvo que abjure de dicho partido y de los hechos que motivan tal ilegalización.

$5^{\text {a }}$. Todavía el legislador orgánico tiene un gesto favorable al mandato representativo cuando da por buena la declaración unipersonal de independencia del diputado o senador en la que dice separarse de y rechazar los hechos que han motivado la ilegalización del partido político de referencia. Pero tal declaración no debería exigirse de ningún modo (y menos aún su consecuencia negativa) porque la independencia del parlamentario es un elemento de Derecho constitucional necesario de su estatuto jurídico y su declaración no le añade nada.

Vista por el envés, esa exigencia de una declaración de rechazo busca fomentar la indisciplina del parlamentario respecto de «su» formación política, Pero eso también implica la consideración de que la relación «normal» entre ambos es la de sometimiento del parlamentario a la disciplina de dicha formación.

Mejor sería incluir en el protocolo de la toma de posesión, junto al juramento de la Constitución, la condena del terrorismo con mención expresa de los grupos terroristas of $i$ -

(C) UNED. Revista de Derecho Político 
cialmente censados, satisfecho lo cual, no se debe volver a exigir nada parecido durante el tiempo de mandato a ningún representante.

$6^{a}$. La torpeza del legislador a la hora de dificultar hasta el extremo el fenómeno del transfuguismo para mejor consolidar la democracia de partidos lo ha llevado a consagrar la irresponsabilidad política de los Alcaldes en un muy elevado número de municipios en los que se da una relación de fuerzas políticas similar a la señalada en este estudio.

$7^{\text {a }}$. Las dos reformas aquí comentadas son tan toscas que tienen bien difícil pasar indemnes el fielato del Tribunal Constitucional en cuanto haya una cuestión de inconstitucionalidad o un amparo seguido de una autocuestión del propio Tribunal Constitucional.

\title{
Title
}

Requiem for the representative mandate

\section{Resumen}

Se estudian en este trabajo dos aspectos de las reformas a la Ley Orgánica del Régimen Electoral General electorales aprobadas a principios de 2011: las medidas adoptadas para combatir el transfuguismo y las arbitradas para poder expulsar de los órganos representativos a los miembros que hayan sido elegidos en candidaturas de partidos y otras formaciones políticas que ulteriormente resultaren ilegalizadas. Unas u otras medidas adolecen de inconstitucionalidad por vulneración del principio de mandato representativo. En una segunda parte del trabajo se pone de relieve que este principio no ha funcionado correctamente nunca porque los presupuestos en los que se asienta lo llevan a la parálisis y, al parecer, se camina hacia su superación en los regímenes demoliberales, pero hurtando la correspondiente reforma constitucional.

\begin{abstract}
The article analyses two different aspects of the amendments of the Organic Law on the General Electoral Regime which were approved at the beginning of 2011: the measures to combat turncoatism and the ones adopted to expel from the representative institutions the elected candidates of political parties or similar associations which afterwards are declared illegal. All these measures are unconstitutional since they infringe the principle of the representative mandate. In the second part of the article it is pointed out that this principle never was applied cor-
\end{abstract}


rectly since its basis makes it inefficient. It seems that democratic-liberal regimes will do without this principle in the near future, however, without the due constitutional reform.

\section{Palabras claves}

Soberanía nacional, transfuguismo, terrorismo, representación, mandato representativo, mandato de partidos, inelegibilidad, incompatibilidad, revocación.

\section{Key words}

National sovereignty, turncoatism, terrorism, representation, representative mandate, mandate by the political parties, ineligibility, incompatibility, repeal. 
